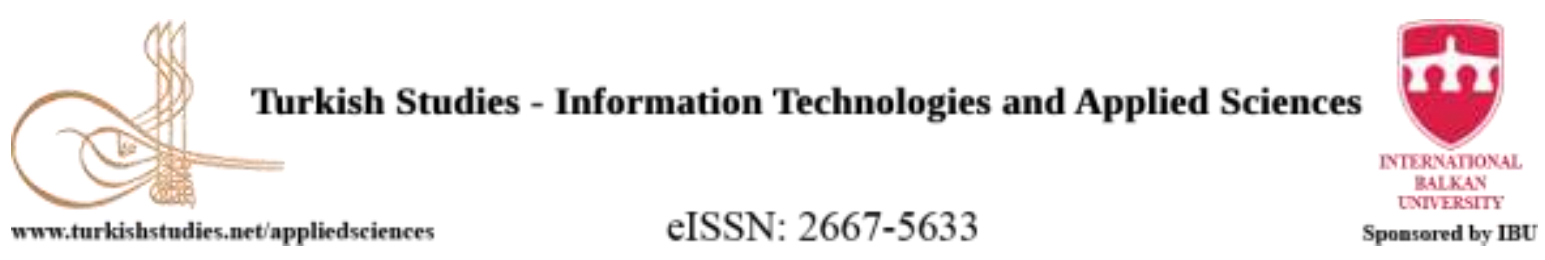

Research Article / Araştırma Makalesi

\title{
Öğrencilerin 21. Yüzyıl Öğrenme Becerileri İçin Veri Toplama Aracı: Geçerlik ve Güvenirlik Çalışması
}

Data Collection Tool for Students' 21 st Century Learning Skills: A Study of Validity and Reliability

\author{
Selami Eryılmaz
}

\begin{abstract}
The people need to have high communication, cooperating, problem-solving, knowing the ways to reach the information, using technology at the highest level while reaching information, having a creative and critical thinking perspective, open to new ideas, fulfilling their responsibilities with self-management, social and cultural skills, productive and leadership skills to have a better education or business life in this century. In this study, the scale used in a study on 21-st century learning measures in West Virginia; Critical Thinking Skills, Collaboration Skills, Communication Skills, Creativity and Innovation Skills, Self-Direction Skills, Global Connections, Local Connections and Using Technology as a Tool. It is a five-step Likert-type scale, consisting of 8 subscales and 73 items each with two factors. The data obtained by applying the 8 sub-scale data collection tool final scale form to 331 students consisting of students were processed into the SPSS-21 program. According to the confirmatory factor analysis; The scale consists of two sub- and eight main factors. When the factor loadings of the items in the factors, the eigenvalues of the factors and the explained variance ratios are considered, it can be said that the scale has construct validity. In order to determine the validity of the scale (similar scales or present), the related field literature review was conducted; The validity of similar scales could not be calculated because a similar scale could not be found in terms of content and purpose. For the internal consistency of the scale; Cronbach alpha reliability coefficients were examined. According to the obtained values, it can be said that the scale can make reliable measurements.
\end{abstract}

Structured Abstract: Many expert have focused on the need for students to acquire broader applicable skills such as problem-solving and critical thinking, while technology and economic changes have led to more uncertainty about certain knowledge and skills needed for tomorrow's jobs.

It is important to include 21 st-century skills in educational curricula to gain individuals. If there is a skill and it is thought to be gained through training, it is necessary to measure those skills. Standards of skills to be acquired by individuals should be determined and appropriate scales should be developed according to these standards.

The 21st-century learning assessment questionnaire is an assessment tool prepared for West Virginia 21st century teaching and learning research (West Virginia Board of Education, 2008). In this study, scales prepared separately for learners and trainers. The reliability values of the scales used in this study were found to be high (std. Alpha> .90, correlations between items> .58). The English versions of this scale prepared for

\footnotetext{
${ }^{*}$ Doç.Dr., Gazi Üniversitesi, Üniversite, Eğitim Fakültesi, Bilgisayar ve Öğretim Teknolojileri Eğitimi Bölümü Assoc. Prof. Dr., Gazi University, Gazi Faculty of Education, Department of Computer Education and Instructional Technology ORCID 0000-0002-6507-740X

selamieryilmaz@gazi.edu.tr

Cite as/ Atıf: Eryılmaz, S. (2020). Öğrencilerin 21. yüzyıl öğrenme becerileri için veri toplama aracı: Geçerlik ve güvenirlik çalışması. Turkish Studies - Applied Sciences, 15(3), 301-323.
} https://dx.doi.org/10.47844/TurkishStudies.44127

Received/Geliş: 09 June/Haziran 2020

Accepted/Kabul: 20 September/Eylül 2020

Copyright $($ INTAC LTD, Turkey

Checked by plagiarism software

Published/Yayın: 25 September/Eylül2020

CC BY-NC 4.0 
both teacher and students have been translated into Turkish. Conceptualization of skills in the research conducted in England for the data obtained from the international Innovative Teaching and Learning study. Deep Learning framework from William and Flora Hewlett Foundation (2010) and 21st Century Skills Partnership information (p21.org). Even though there seems to be a consensus about what 21st-century skills are, there are also different opinions. Literature says, 21 st-century skills referred to as P21 are discussed within the general framework given below.

Critical Thinking Skills; analyze complex problems, investigate questions without clear answers, evaluate different perspectives or sources. It can be explained as drawing appropriate conclusions based on information, findings and reasons. Collaboration Skills; They can work together to solve problems or answer questions, work effectively and respectfully in teams to achieve a common goal, and take joint responsibility to complete a task. Communication skills; It refers to the ability to organize students' thoughts, data and findings and to use them verbally and in writing, as well as to effectively share them using various media. Creativity and Innovation Skills; explain how students produce and develop solutions to complex problems or tasks, such as synthesis, analysis, and then bringing together and presenting what they have learned in new and original methods. Self Directional Skills; explains that they can take the responsibility of determining the subjects to be continued and processed for their learning, reviewing their work and organizing the feedback. Global Connections; It refers to the ability to understand global, geopolitical problems including the awareness of other countries of geography, culture, language, history, and literature. Local Connections; It means being able to apply their learning to local contexts and community problems. Using Technology as a Learning Tool; It is explained as students' ability to manage their learning and produce products using appropriate information and communication technologies. Content validity in the related research was obtained by examining the literature from various sources. Students' 21st Century Skills according to various sources;

In this study, it includes the stages of developing a scale to analyze the validity and reliability of a measurement tool consisting of different subscales, whose structure based on the literature is defined to measure the behaviours and attitudes of students while performing activities in the 21 st-century learning processes.

Data collection tool; "Critical Thinking Skills", "Collaboration Skills", "Communication Skills", "Creativity and Innovation Skills", "Self Orientation Skills", "Global Connections", "Local Connections" as sub-scale titles on 21 st-century learning measures. and 8 subscales, each with two factors, that measure students' frequency of behaviour and attitudes towards activities, "Using Technology as a Learning Tool". Each scale is designed in a 5-point Likert structure as "rarely (1), occasionally (2), medium size (3), mostly (4) very large (5)". Since all items belonging to 8 subscales that make up the data collection tool were designed as positive items, reverse scoring method was not used.

331 high school students, 9th, 10th, 11th, and 12th grades, constitute the study group of the research. There are $192(58.0 \%)$ female students and 139 (42.0\%) male students who participated in the study. The groups, $96(29.0 \%)$ students from 9th grade, 84 (25.4\%) students from 10th grade, $92(27.8 \%)$ students from 11 th grade and there are 59 (17.8) students from 12th grade. Since it was a scale development study for the study, without choosing a sample from the universe, students from each grade level studying at high school were included in the study group with the criterion sampling method suitable for the level.

The developed 8 sub-scale data collection tool final scale form 331 students, and SPSS-21 package program was used to process the data. Confirmatory factor analysis was applied to test whether the structure of the items previously defined based on the conceptual framework was confirmed with the data obtained. For the reliability of the scale, the Cronbach Alpha analysis and the AMOS-21 package program were used to perform the "Confirmatory Factor Analysis (CFA)". Confirmatory factor analysis (CFA) is a type of structural equation modelling (SEM). Schermelleh-et al. (2003) used the criteria specified. These criteria are shown in Figure-1. 


\begin{tabular}{|c|c|c|}
\hline Fit Mvenase & Good Fi & Aeraptuble Fit \\
\hline$x^{7}$ & $0 \leq x^{2} \leq 2 d f$ & $2 d f<x^{2} \leq$ adf \\
\hline s valite. & $05<p \leq 1.00$ & $A 1 \leq p \leq 06$ \\
\hline$x^{2} / d f$ & $0 \leq x^{3} / 4,4 \leq 2$ & $2<x^{2} / d f \leq 3$ \\
\hline RMSEA & A $\leq$ R.MSEA $\leq .05$ & $.05<R A M S E A \leq .05$ \\
\hline $\begin{array}{l}\text { jovalue for thet of cloee fit } \\
\text { (RMSEA }<.05)\end{array}$ & $10<\mu \leq 1,00$ & $.06 \leq p \leq 10$ \\
\hline Confidence interval (C) & $\begin{array}{l}\text { cluee to RMSEEA, } \\
\text { kat bouminary of } \mathrm{CI}=\infty 0\end{array}$ & ckne to RMSE,A \\
\hline SRMR & $0 \leq$ SRMR 5 . AT & $05<$ SRMR $\leq .10$ \\
\hline NFI & $95 \leq N F 7 \leq 100$ & $.90 \leq N F 7<.96$ \\
\hline NNET & $97 \leq N N F 7 \leqslant 1.00$ & $95 \leq N N F T<.9 \%$ \\
\hline$C F I$ & $.97 \leq C F I \leq 100$ & $.95 \leq C F 7<.9 T$ \\
\hline GFI & $.90 \leq C F I \leq 1.00$ & $.90 \leq a F T<.90$ \\
\hline$\triangle G F I$ & $\begin{array}{c}90 \leq A G F I \leq 190, \\
\text { dom to } G F 7\end{array}$ & $\begin{array}{l}85 \leq A G F T<90, \\
\text { cloes to } G F I\end{array}$ \\
\hline
\end{tabular}

Figure 1: Criteria Suggestions for Model Evaluation

The validity of the scale was tested by examining the factor analysis (1) and discrimination (2) features. According to the results obtained using confirmatory factor analysis techniques; The scale consists of two sub-factors and eight main factors. Considering the factor loadings, eigenvalues and variance rates of the items in the factors, it can be said that it is a scale with construct validity.

According to the results of both primary and secondary confirmatory factor analysis, the observed values of the scale model indicate that the data has an acceptable fit; that means, it was seen as a result of the confirmatory factor analysis that this model obtained was verified by the data. This study identified a list of 21 st-century skills-based on other available research, what skills students were taught most frequently and comprehensively, Students often noted that they were trying to improve their skills, at least effectively assessing those skills. Finally, this study could assist in the development of survey tools for future research on teaching 21 st-century skills.

Keywords: 21st-century skills, scale development, 21st-century learning skills, 21st-century learning measures

Öz: Bu çalışmada öğrencilerin 21. yüzyıl becerilerini öğrenmek amacıyla ölçek geliştirilmiştir. Bu yüzyıl bireyleri eğitim ve iş hayatında yer bulabilmek için; iletişim becerileri yüksek ve birlikte işbirliği yapabilen, problem çözebilen ve ihtiyaç duyduğu bilgiye ulaşım yollarının neler olduğunu bilen ve bilgiye ulaşırken teknoloji en üst düzeyde kullanabilen, yaratıcı ve eleştirisel düşünme bakış açısına sahip, yeni fikirlere açık, sorumluluklarını öz-yönetim becerileri ile yerine getiren, sosyal ve kültürel becerileri gelişmiş, üretken ve liderlik becerilerine sahip olunması gerekmektedir. Batı Virginia'da 21. yüzyıl öğrenme ölçümleri üzerine yapılan bir çalıșmada; "Eleştirel Düşünme Becerisi”, "İşbirliği Becerileri”, "İletişim Becerisi”, "Yaratıcılık ve İnovasyon Becerileri”, “Özyönelim Becerileri”, "Küresel Bağlantılar”, "Yerel Bağlantılar” ve "Teknolojiyi Öğrenmeyi Bir Araç Olarak Kullanma” olmak üzere sekiz alt faktörü olan bir ölçektir. Bu ölçek öğrencilerin bu faktörlere iliş̧kin davranış sıklıkları ve tutumlarını ölçmek amacı ile oluşturulmuştur. Likert tipi bir ölçek olup, her biri iki faktörlü olan 8 alt ölçekten ve 73 maddeden oluşmaktadır. Türkçe’ye uyarlanan veri toplama aracının maddelerin hepsi olumlu madde olarak tasarlandığından ters puanlama yoluna gidilmemiştir. Geliştirilen 8 alt ölçekli veri toplama aracı nihai ölçek formu 331 öğrenciye uygulanmış ve verilerin çözümünde SPSS-20 paket programı kullanılmıştır. Ölçeğin; geçerlik, faktör analizi ve ayırt edicilik özellikleri incelenmiştir. Doğrulayıcı faktör analizine göre; ölçek iki alt ve sekiz ana faktörü kapsamaktadır. Ölçeğe ait maddelerin faktörlerin öz değerleri, açıklanan varyans ve faktör yükleri değerleri ele alındığında yapı geçerliğinin olduğu sonucuna ulaşılabilir. Ölçeğin iç tutarlığını Cronbach alpha güvenirlik(iki eş yarılar korelasyonu) katsayısı ele alınmıştır. Sonuç olarak ölçeğinin, lise öğrencilerinin tutumlarının belirlenmesini sağlayan geçerli ve güvenilir bir araç olduğu ortaya konmuştur. Bu ölçek tekrar düzenlenerek lisans ögrencilerine de uygulanabilir.

Anahtar Kelimeler: 21. YY becerileri, ölçek geliştirme, 21. yüzyıl becerilerini öğrenme, 21. yüzyıl öğrenme ölçümleri

www.turkishstudies.net/appliedsciences 


\section{Giriş}

Bireylerin iş bulabilmeleri için temel bilgi ve temel becerileri ile aldıkları okul bitirme belgeleri yetersiz kalmaktadır. Okulların sağladığı temel beceriler ilave olarak, bu yüzyıla ait olarak nitelendirilen birçok beceriyi kazanmış olmaları gerekmektedir. Geçmişte bilgi merkezli bir değerlendirme yapılırken son yüzyılın bu günlerinde tek başına bilgi yeterli olmamaktadır. Bu yüzyıl bireylerin eğitim ve iş hayatında yer bulabilmek için; iletişim becerileri yüksek ve birlikte işbirliği yapabilen, problem çözebilen ve ihtiyaç duyduğu bilgiye ulaşım yollarının neler olduğunu bilen ve bilgiye ulaşırken teknoloji en üst düzeyde kullanabilen, yaratıcı ve eleştirisel düşünme bakış açısına sahip, yeni fikirlere açık, sorumluluklarını öz-yönetim becerileri ile yerine getiren, sosyal ve kültürel becerileri gelişmiş, üretken ve liderlik becerilerine sahip olunması gerekmektedir (Eryilmaz vd. 2015:221) . Bilim ve teknolojide yaşanan hızlı değişme ve gelişmeler bu yüzyılın bilim ve teknoloji merkezi olmasına neden olmuştur.

Yeni teknolojiler, gelişmekte olan dijital ve çevrimiçi hizmetlerin en sık kullanıcıları olan 21. yüzyıl çocuklarının hayatlarında temel değişiklikler yaratmaktadır. Çocuklar Instagram ve You Tube gibi dijital platformlarla büyüyorlar ve konuşmayı öğrenmeden önce bir tabletin nasıl kullanılacağını öğreniyorlar. Digital teknoloji çocukların büyüme, öğrenme, oyun ve etkileşim biçimlerini de etkilemektedir.

Teknolojinin hızlı gelişimi, bilgiye olan artan ihtiyacı nedeniyle yirminci yüzyıl sanayi toplumundan 21. yüzyılın bilgi toplumuna dönüşüm hızlı olmuştur. Hızlıca gelişen bu değişime bireylerin uyum sağlamaları, iş dünyasından artan şekilde gelen değişim talepleri bireyler tarafından yerine getirilebilmesi için 21.yüzyılın yeni becerilerini hızlı bir şekilde kazanmaları gerekmektedir. İş dünyasından gelen bu yeni taleplere uyum sağlayamayan, teknolojiyi kullanamayan, yeni teknolojilere ve fikirlere uyum sağlayamayan bireylerin yakın gelecekte ve günümüzde başarılı olmayacakları ifade edilmektedir.

Teknoloji ve ekonomik değişimler yarının işleri için ihtiyaç duyulan belli bilgi ve beceriler hakkında daha fazla belirsizliğe yol açarken pek çok analist öğrencilerin sorun çözme ve kritik düşünme gibi daha geniş ölçüde uygulanabilir beceriler edinme gereksinimine odaklanmıştır.

21. yüzyıl becerilerinin bireylere kazandırılması için eğitim müfredatlarına dâhil edilmesi önem arz etmektedir. Bir beceri varsa ve eğitim yoluyla kazandırılması düşünülüyorsa o becerileri de ölçebilmek gerekmektedir(Hixson, 2012). Bireylere kazandırılacak becerilerin standartları belirlenmeli ve bu standartlara göre uygun ölçekler geliştirilmelidir.

21. yüzyıl öğrenme ölçme anketi, Batı Virginia 21. yüzyıl öğretme ve öğrenme araştırması için hazırlanmış bir ölçme aracıdır(West Virginia Board of Education, 2008). Bu araştırmada öğrenenler ve öğreticiler için ayrı ayrı hazırlanan ölçekler kullanılmıştır. Bu araştırma da kullanılan ölçeklerin güvenilirlik değerleri yüksek çıkmıştır(std. Alfa $>.90$, maddeler arası korelasyonlar> .58). . Bu ölçeğin hem öğreten, hem de öğrenen için hazırlanan İngilizce sürümleri Türkçeye çevrilmiştir. İngiltere'de yapılan araştırmada becerilerin kavramsallaştırılması uluslararası Yenilikçi Öğretme ve Öğrenme çalışmasından elde edilen veriler için (Shear vd. 2010:32) ve William and Flora Hewlett Foundation (2010) 'dan Derin Öğrenme çerçevesine ve 21. Yüzyıl Becerileri Ortaklığı bilgileri (p21.org) temel alınmıştır. 21. yüzyıl becerilerinin neler olduğu ile ilgili genel bir konsensüs sağlanmış görülse bile farklı görüşler de yer almaktadır. Alan yazında, P21 olarak anılan 21. yüzyıl becerilerinin aşağıda verilen genel çerçeve içerisinde ele alınmıştır(West Virginia Department of Education, 2008)

Eleştirel Düşünme Becerileri; karmaşık problemleri analiz edebilme, net cevapları olmayan soruları araştırabilme, farklı bakış açılarını veya kaynaklarını değerlendirebilir. Bilgi, bulgu ve gerekçelere dayanarak uygun sonuçlar çıarmak şeklinde açıklanabilir. 
İşbirliği Becerileri; problemleri çözmek veya soruları cevaplamak için birlikte çalışabilecekleri, ortak bir amacı gerçekleştirmek için ekiplerde etkin ve saygılı bir şekilde çalışabilecekleri ve bir görevi tamamlamak için ortak sorumluluk üstlenebilecekleri şeklinde tanımlanır.

İletişim Becerileri; öğrencilerin düşüncelerini, verilerini ve bulgularını düzenleyebilme ve bunları sözlü ve yazılı olarak kullanmanın yanı sıra çeşitli medya aracı kullanarak etkin bir şekilde paylaşmalarını yapabilmeyi ifade eder.

Yaratıcılık ve Yenilik Becerileri; öğrencilerin sentez, analiz ve daha sonra öğrendiklerini yeni ve orijinal yöntemlerle bir araya getirip sunma gibi karmaşı problemlere veya görevlere çözümler üretip geliştirmelerini açıklar.

Kendine Yönlendirme Becerileri; kendi öğrenmeleri için sürdürülecek ve işlenecek konuları belirleyerek, çalışmalarını gözden geçirip geri bildirimleri düzenleyecek sorumluluğu alabilmelerini açıklar.

Küresel Bağlantılar; diğer ülkelerin coğrafya, kültür, dil, tarih ve edebiyat bilinci dahil olmak üzere küresel, jeo-politik sorunları anlayabilmeyi ifade eder.

Yerel Bağlantılar; öğrendiklerini yerel bağlamlara ve topluluk sorunlarına uygulayabilmeleri anlamına gelir.

Teknolojiyi Öğrenme Aracı Olarak Kullanmak; öğrencilerin öğrenmelerini yönetebilmelerini uygun bilgi ve iletişim teknolojilerini kullanarak ürünler meydana çikarabilmeleri şeklinde açıklanır. İlgili araştırmada içerik geçerliliği çeşitli kaynaklardan literatürün incelenmesi sonucu elde edilmiştir(Shear vd. 2010:45). Bu kaynakta öğrencilerin 21. Yüzyıl Becerileri;

Öğrenciler üretmenin ötesinde, yeni bilgi oluşturma, önceden yeni bir problemi çözer, çözüm seçeneklerinden birini seçer ve seçtiği çözümleri gerçek ortamda yenilikçi olarak uygular, fikirlerini açik ve ilgi çekici şekillerde sunar, bir konu veya tema hakkında yeterli kanıt sunar, birlikte gruplar halinde çalışırlar, roller üstlenirler ve ortak bir iş ürünü oluştururlar, çalışmalarını planlar ve izler, geri bildirime veya öz değerlendirmeye dayalı düzenlemeler yaparlar, Öğrenciler bilgi oluşturmak için BİT'i kullanır; ne zaman, nerede ve nasıl kullanılacağını seçerler; çevrimiçi kaynakların güvenilirliğini ve konuları ile ilgi düzeylerini değerlendirir ve karar verirler.

\section{Yöntem}

Bu araştırmada öğrencilerin 21. Yüzy1l öğrenme süreçlerindeki faaliyetleri gerçekleştirirken göstermiş olduğu davranışları ve tutumlarını ölçmek için literatüre dayalı yapısının tanımlandığı farklı alt ölçeklerden oluşan bir ölçme aracının geçerlik ve güvenirlik analizlerini yapmak amacı ile bir ölçek geliştirme aşamalarını içermektedir.

\section{Katılımcilar}

Araştırmaya 9, 10, 11, ve 12. sınıf olmak üzere lise düzeyinde öğrenim gören 331 öğrenci araştırmanın çalışma grubunu oluşturmaktadır. Araştırmaya katılan $192(\% 58,0)$ kız öğrenci ve 139 $(\% 42,0)$ erkek öğrenci bulunmaktadır. Çalışma grubunda 9. sınıf düzeyinde öğrenim gören 96 $(\% 29,0)$ öğrenci, 10. sınıf düzeyinde öğrenim gören $84(\% 25,4)$ öğrenci, 11. sınıf düzeyinde öğrenim gören $92(\% 27,8)$ öğrenci ve 12. sınıf düzeyinde öğrenim gören $59(17,8)$ öğrenci bulunmaktadır. Araştırmanın amacına yönelik olarak ölçek geliştirme çalışması olduğundan evrenden örneklem seçimi yoluna gidilmeden düzeye uygun olan ölçüt örnekleme yöntemi ile lise de öğrenim gören her bir sınıf düzeyinden öğrenci çalışma grubuna dahil edilmiştir. 


\section{Veri Toplama Aracı}

21. yüzyıl öğrenme ölçümleri üzerine kavramsal çerçevede alt ölçek başlıkları olarak "Eleştirel Düşünme Becerisi”, "İşbirliği Becerileri”, "İletişim Becerisi”, "Yaratıcılık ve İnovasyon Becerileri", "Özyönelim Becerileri", "Küresel Bağlantılar", "Yerel Bağlantılar" ve "Teknolojiyi Öğrenmeyi Bir Araç Olarak Kullanma" olmak üzere öğrencilerin faaliyetlere ilişkin davranış sıklıkları ve tutumlarını ölçen her biri iki faktörlü 8 alt ölçek tasarlanmıştır. Her bir ölçek "nadiren (1), ara sıra (2), orta ölçüde (3), büyük ölçüde (4) ve çok büyük ölçüde (5)" olmak üzere 5'li likert yapıda tasarlanmıştır. Veri toplama aracını oluşturan 8 alt ölçeğe ait maddelerin hepsi olumlu madde olarak tasarlandığından ters puanlama yoluna gidilmemiştir.

\section{Verilerin Analizi}

Geliştirilen 8 alt ölçekli veri toplama aracı nihai ölçek formu öğrencilerden oluşan 331 kişiye uygulanmış, verilerin işlenmesi için SPSS-21 paket programı kullanılmıştır. Elde edilen veriler ile maddelerin daha önceden kavramsal çerçeveye dayalı tanımlanan yapısının doğrulanıp doğrulanmadığını test etmek için doğrulayıcı faktör analizi uygulanmıştır. Ölçeğin güvenirliği için Cronbach Alpha analizi ve "Doğrulayıcı Faktör Analizi (DFA)"ni yapabilmek için AMOS-21 paket programı kullanılmıştır. Doğrulayıcı faktör analizi (DFA) yapısal eşitlik modellemesinin (YEM) bir türüdür(Şimşek, 2007:7). DFA sonucunda uyum iyiliği indekslerinin değerlendirilmesi için Schermelleh-vd. (2003) tarafından belirtilen ölçütler kullanılmıştır. Bu ölçütler Şekil 1'de görülmektedir.

\begin{tabular}{|c|c|c|}
\hline Fit Measiare & Good Fit & Accoptable Fit \\
\hline$\overline{x^{2}}$ & $0 \leq \mathrm{x}^{2} \leq 2 d f$ & $2 d f<x^{2} \leq 3 d f$ \\
\hline$p$ value & $05<p \leq 1.00$ & $01 \leq p \leq .05$ \\
\hline$x^{2} / d f$ & $0 \leq x^{2} / d f \leq 2$ & $2<x^{3} / d f \leq 3$ \\
\hline RMSEA & $0 \leq R M S E A \leq .05$ & $05<R M S E A \leq, 08$ \\
\hline $\begin{array}{l}\text { p value for test of clowe fit } \\
(\text { RMSEEA }<.05)\end{array}$ & $.10<p \leq 1.00$ & $.05 \leq p \leq .10$ \\
\hline Coufidence interval (Cl) & $\begin{array}{l}\text { close to } R M S E A \\
\text { left bommiary of } \mathrm{CI}=-00\end{array}$ & cloenc to RMSSEA \\
\hline SRMR & $0 \leq S R M R \leq .05$ & $.05<S R M R \leq .10$ \\
\hline$N F I$ & $.95 \leq N F I \leq 1.00 \%$ & $.90 \leq N F I<.95$ \\
\hline NNFI & $97 \leq N N F I \leq 1.00^{\circ}$ & $95 \leq N N F I<.97$ \\
\hline CFI & $.97 \leq C F I \leq 1.00$ & $.95 \leq C F I<.97$ \\
\hline GFI & $95 \leq G F I \leq 1.00$ & $.90 \leq G F I<.95$ \\
\hline$A G F I$ & $\begin{array}{c}90 \leq A G F I \leq 1,00, \\
\text { cloere to } G F I\end{array}$ & $\begin{array}{c}.85 \leq A G F I<.90 \\
\text { close to } G F I\end{array}$ \\
\hline
\end{tabular}

Şekil 1: Model Değerlendirmeye Yönelik Ölçüt Önerileri

\section{Bulgular ve Yorum}

\section{Analizleri}

21. Yüzyıl Öğrenme Ölçümleri Veri Toplama Aracının Geçerlik ve Güvenirlik

\section{Eleștirel Düşünme Becerisi Ölçeğinin Geçerlik ve Güvenirlik Analizi}

Lise düzeyinde öğrenim gören 331 kişilik çalışma grubuna uygulanarak 2 faktörlü olmak üzere birinci faktöründe faaliyetlere ait davranış sıklıklarını ölçen 6 madde ve ikinci faktöründe tutumlarını ifade eden 3 madde olmak üzere 9 maddelik 2 faktörlü yapının olup olmadığını belirlemek amacıyla çalışma yapılmıştır. Doğrulayıcı Faktör Analizi (DFA) ile ölçeğin doğrulama işlemi yapılmıştır. Bu doğrulama işlemi yapı geçerliğinin bir örneği şeklinde uygulanmıştır. DFA modeline göre 2 faktörlü ve 9 maddelik yapıda uyumsuz hiçbir maddenin olmadığı maddelerin uyum istatistikleri incelendiğinde sonuca varılmıştır. Uyum göstergelerine diğerlerine ilişkin veriler ve dağılım Tablo 1'de verilmektedir. 
Tablo 1: Eleştirel Düşünme Becerisi Ölçeğinin Geçerlik Çalışmasına İlişkin Uyum İndeks Değerleri

\begin{tabular}{|c|c|c|c|c|c|c|c|}
\hline \multirow{2}{*}{ Uyum İndeks } & $\chi^{2 /(\mathrm{df})}$ & RMSEA & $\begin{array}{l}\text { TLI/NNF } \\
\text { I }\end{array}$ & CFI & NFI & $\begin{array}{l}\text { AGF } \\
\text { I }\end{array}$ & GFI \\
\hline & $\begin{array}{l}66,59 /(26)=2.5 \\
6\end{array}$ & 0.069 & 0.95 & 0.96 & 0.93 & 0,92 & 0,96 \\
\hline Uyum Ölçütleri & Kabul & Kabul & Kabul & Kabul & Kabul & İyi & $\begin{array}{l}\text { İyi } \\
\end{array}$ \\
\hline
\end{tabular}

Tablo 1'de eleştirel düşünme becerisi ölçeğinin 1. Düzey 2 faktörlü 9 maddelik ölçme modelinin uyum indeks sonuçları ele alınmış ve Ki-Kare değeri $2<\chi 2 /(\mathrm{df})=2.56 \leq 3$ kritik veri aralığında olduğu görülmüsstür. Bu sonuca göre kabul edilebilir uyum verdiği ifade edilebilir. Elde edilen RMSEA değerinin 0.08 ölçüt değerin altında olduğundan dolayı uyum indeksinin kabul edilebilir olduğunu gösterir. Uyum indeks değerleri olan TLI, NFI ve CFI'nın elde edilen değerleri ile Şekil-1'de verilen ölçüt kriter değerler ile karşılaştırarak incelendiğinde makul düzeyde uyum sağladıkları söylenebilir. Yine aynı şekilde elde edilen GFI ve AGFI değerleri ile Şekil-1'de verilen ölçüt kriter değerler ile karşılaştırıldığında iyi uyum sağladıkları söylenebilir (Schermelleh vd. 2003:32). "Eleştirel Düşünme Becerisi Ölçeği”ne ait 1. Düzey 2 faktörlü DFA modeli Şekil-2'de görülmektedir.

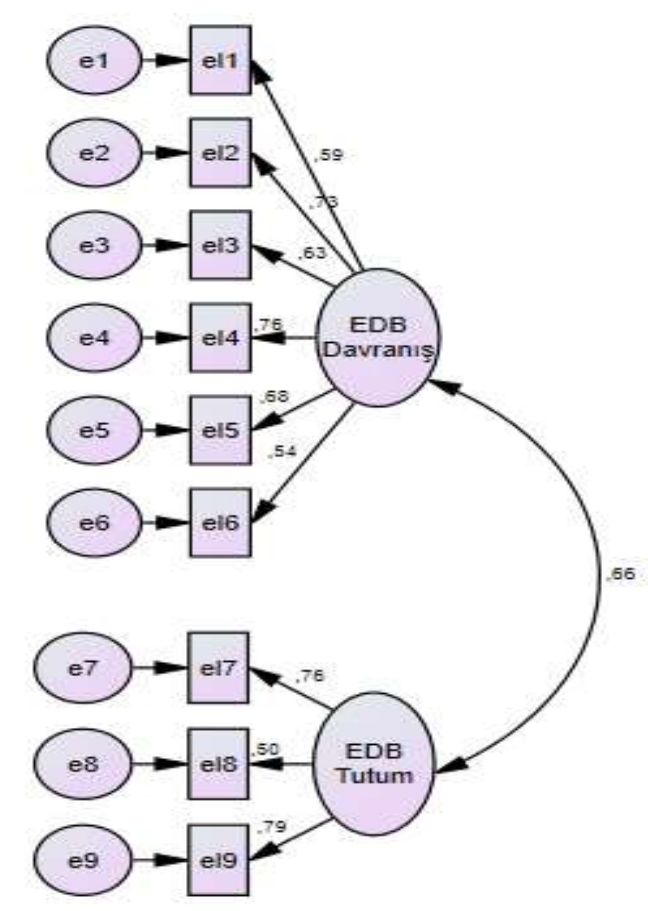

Şekil 2: Eleştirel Düşünme Becerisi Ölçeğine İlişkin Hazırlanan 1. Düzey 2. Faktörlü DFA Modeli

Eleştirel Düşünme Becerileri Ölçeğinin genel ve iki alt faktörüne ilişkin tanımlanan yapısının doğrulanması işin yapılan işlemlerde kullanılan örneklemden elde edilen güvenirlik katsayıları Tablo 2'de yer almaktadır. 
Tablo 2: Eleştirel Düşünme Becerisi Ölçeğinin Genel ve Faktörlerinin Cronbach Alpha Güvenirlik Sonuçları

\begin{tabular}{cccc}
\hline & Eleştirel Davranış & Eleştirel Tutum & $\begin{array}{c}\text { Eleştirel Düşünme } \\
\text { Becerisi }\end{array}$ \\
\hline Madde Sayıs1 & 6 & 3 & 9 \\
\hline Cronbach $\alpha$ &, 81 &, 72 &, 84 \\
\hline
\end{tabular}

Tablo 2'de ölçeğin test sonuçlarına bakılarak iç tutarlılık ölçüsü olan Cronbach alpha katsayısı hesaplanmıştır. Faktörlere ilişkin güvenirlik katsayıları; birinci faktör 0,81, ikinci faktör 0,72 ve ölçeğin geneli 0,84 olarak hesaplanmıştır. Cronbach Alpha güvenirlik değeri; $0,60-0,80$ aras 1 kabul edilebilir, 0,80-0,90 arası yüksek, 0,90-1,00 arası ise çok yüksek düzeyde güvenilir olduğu ifade edilmektedir(Özdamar, 1999:27). Bu ölçütler dikkate alındığında ölçeğin geneli ve alt faktörleri bağlamında güvenirlik düzeylerinin eleştirel düşünme becerisine ait tutum alt faktörü için kabul edilebilir olduğu, davranış alt faktörü ve ölçeğin geneli için yüksek düzeyde olduğu görülmektedir.

\section{İşbirliği Becerileri Ölçeğinin Geçerlik ve Güvenirlik Analizi}

Lise düzeyinde öğrenim gören 331 kişilik çalışma grubuna uygulanarak 2 faktörlü olmak üzere birinci faktöründe faaliyetlere ait davranış sıklıklarını ölçen 6 madde ve ikinci faktöründe tutumlarını ifade eden 3 madde olmak üzere 9 maddelik 2 faktörlü yapının doğrulanıp doğrulanmadığı kontrol edilmeye çalışılmıştır. DFA modeline göre 2 faktörlü ve 9 maddelik yapıda uyumsuz hiçbir maddenin olmadığı maddelerin uyum istatistikleri incelendiğinde sonuca varılmıştır. Uyum göstergelerine ilişkin veriler Tablo 3'te verilmektedir.

Tablo 3: İşbirliği Becerileri Ölçeğinin Geçerlik Çalışmasına İlişkin Uyum İndeks Değerleri

\begin{tabular}{llllllll}
\hline \multirow{2}{*}{ Uyum İndeks } & $\chi 2 /(\mathrm{df})$ & RMSEA & TLI/NNFI & CFI & NFI & AGFI & GFI \\
\cline { 2 - 8 } & $50,25 /(24)=2.09$ & 0.058 & 0.97 & 0.98 & 0.96 & 0,94 & 0,97 \\
\hline Uyum Ölçütleri & Kabul & Kabul & İyi & İyi & İyi & İyi & İyi \\
\hline
\end{tabular}

Tablo 3'te işbirliği becerileri ölçeğinin 1. Düzey 2 faktörlü 9 maddelik ölçme modelinin uyum indeks sonuçları ele alınmış ve Ki-Kare değeri $2<\chi 2 /(\mathrm{df})=2.09 \leq 3$ kritik veri aralığında olduğu görülmüş̧ür. Bu sonuca göre kabul edilebilir uyum verdiği ifade edilebilir. Elde edilen RMSEA değerinin 0.08 ölçüt değerin altında olduğundan dolayı uyum indeksinin kabul edilebilir olduğunu gösterir. Uyum indeks değerleri olan TLI, NFI, CFI, GFI ve AGFI'nın elde edilen değerleri ile Şekil1'de verilen ölçüt kriter değerler ile karşılaştırarak incelendiğinde iyi bir uyum sağladığı söylenebilir (Schermelleh vd. 2003:42). “İşbirliği Becerileri Ölçeği”"ne ait 1. Düzey 2 faktörlü DFA modeli Şekil3'de görülmektedir. 


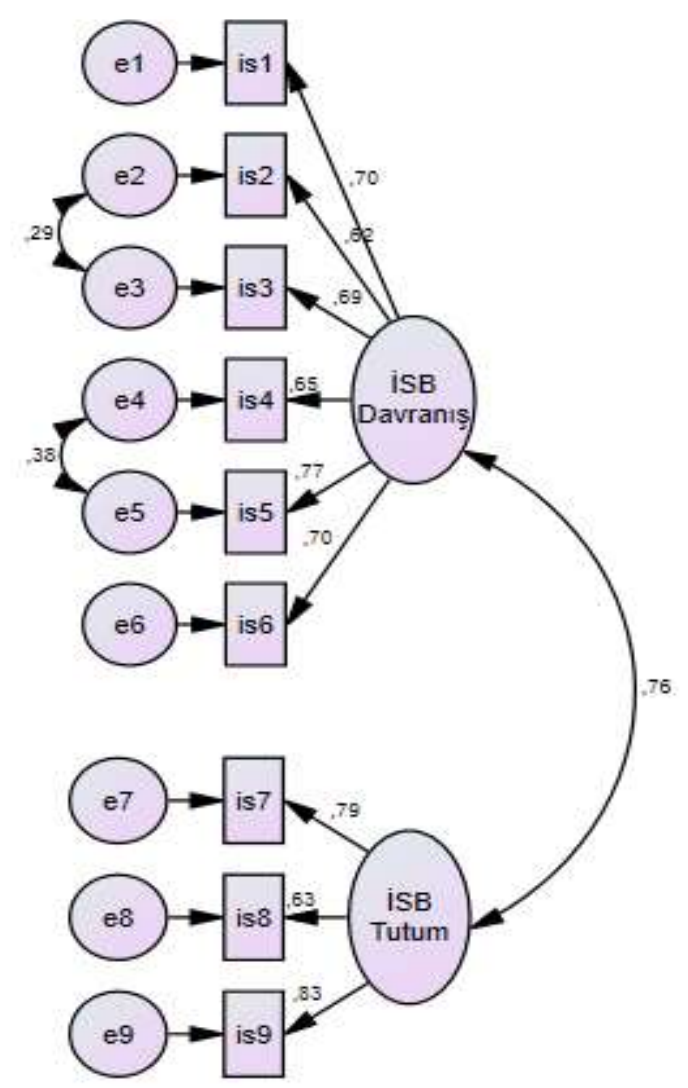

Şekil 3: İşbirliği Becerileri Ölçeğine İlişkin Kurulan 1. Düzey 2. Faktörlü DFA Modeli

İşbirliği Becerileri Ölçeğine ait iki alt faktörü ve ölçeğin geneline ilişkin uygulama yapılan örneklemden elde edilen veriler üzerinden hesaplanan güvenirlik katsayıları Tablo 4 'te verilmiştir.

Tablo 4: İşbirliği Becerileri Ölçeğinin Geneli ve Alt Faktörlerine Ait Cronbach Alpha Güvenirlik Sonuçları

\begin{tabular}{lccc}
\hline & İşbirliği Davranış & İşbirliği Tutum & İşbirliği Becerileri \\
\hline Madde Sayısı & 6 & 3 & 9 \\
\hline Cronbach $\alpha$ &, 85 &, 81 &, 88 \\
\hline
\end{tabular}

Tablo 4 incelediğinde ölçeğin doğrulayıcı faktör analizi yapılarak, güvenirlik için Cronbach alpha iç tutarlılık katsayısı hesaplanmıştır. Birinci faktör 0,85 , ikinci faktöre 0,81 ve ölçeğin geneline ait güvenirlik katsayısı 0,88 olarak hesaplanmıştır. Özdamar (1999)'a göre belirlenen kriterler dikkate alındığında ölçeğin geneli ve alt faktörleri bağlamında yüksek düzeyde olduğu görülmektedir.

\section{İletişim Becerisi Ölçeğinin Geçerlik ve Güvenirlik Analizi}

Lise düzeyinde öğrenim gören 331 kişilik çalışma grubuna uygulanarak 2 faktörlü olmak üzere birinci faktöründe faaliyetlere ait davranış sıklıklarını ölçen 5 madde ve ikinci faktöründe tutumlarını ifade eden 3 madde olmak üzere 8 maddelik 2 faktörlü yapının doğrulanıp doğrulanmadığ 1 kontrol edilmeye çalışılmıştır. DFA modeline göre 2 faktörlü ve 8 maddelik yapıda uyumsuz hiçbir maddenin olmadığı maddelerin $t$ uyum istatistikleri incelendiğinde bu sonuca ulaşılmıştır. Uyum göstergelerine ilişkin veriler Tablo 5'de verilmektedir. 
Tablo 5: İletişim Becerisi Ölçeğinin Geçerlik Uyum İndeks Değerleri

\begin{tabular}{llllllll}
\hline \multirow{2}{*}{ Uyum İndeks } & $\chi 2 /(\mathrm{df})$ & RMSEA & TLI/NNFI & CFI & NFI & AGFI & GFI \\
\cline { 2 - 7 } & $37,66 /(19)=1,98$ & 0.055 & 0.97 & 0.98 & 0.96 & 0,95 & 0,97 \\
\hline Uyum Ölçütleri & İyi & Kabul & İyi & İyi & İyi & İyi & İyi \\
\hline
\end{tabular}

Tablo 5'te iletişim becerisi ölçeğinin 1. Düzey 2 faktörlü 8 maddelik ölçme modelinin uyum indeks sonuçları ele alınmış ve Ki-Kare değeri $0 \leq \chi 2 /(\mathrm{df})=1,98 \leq 2$ kritik veri aralığında olduğu görülmüştür. Bu sonuca göre kabul edilebilir uyum verdiği ifade edilebilir. Elde edilen RMSEA değerinin 0.08 ölçüt değerin altında olduğundan dolayı uyum indeksinin kabul edilebilir olduğunu gösterir. Uyum indeks değerleri olan TLI, NFI, CFI, GFI ve AGFI'nın elde edilen değerleri ile Şekil1'de verilen ölçüt kriter değerler ile karşılaştırarak incelendiğinde iyi bir uyum sağladığ söylenebilir[2]. “İletişim Becerisi Ölçeği”ne ait 1. Düzey 2 faktörlü DFA modeli Şekil 4'te görülmektedir.

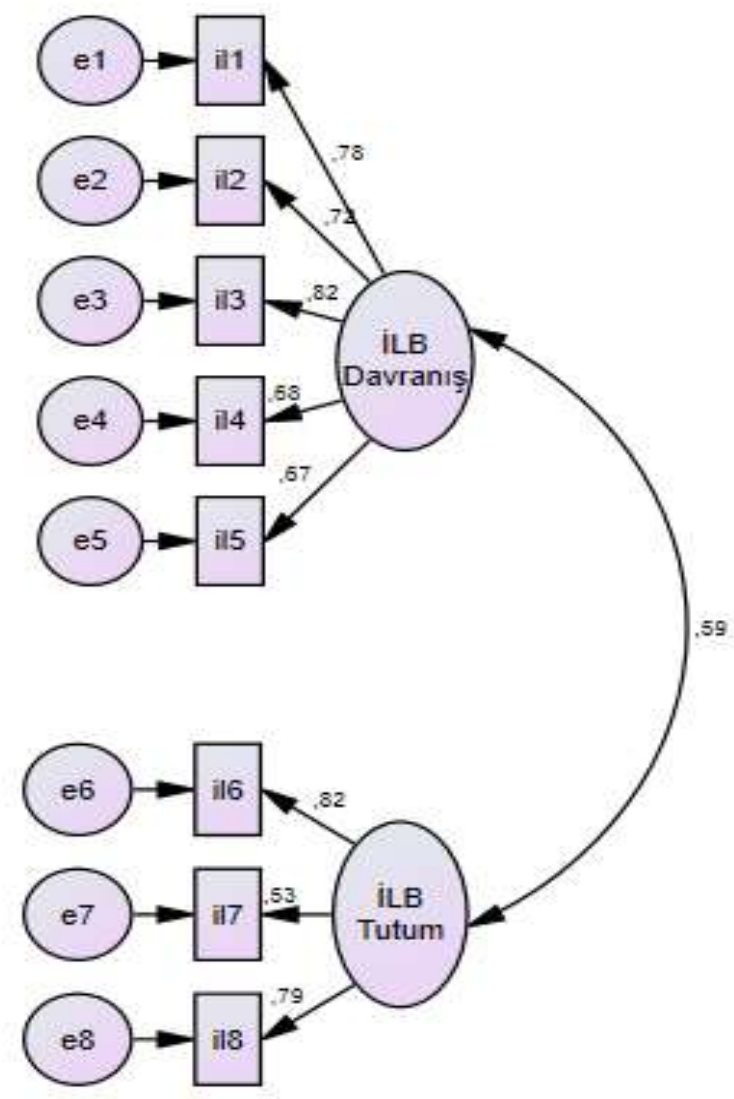

Şekil 4: İletişim Becerisi Ölçeğine İlişskin Kurulan 1. Düzey 2. Faktörlü DFA Modeli

İletişim Becerileri Ölçeğine ait iki alt faktörü ve ölçeğin geneline ilişkin uygulama yapılan örneklemden elde edilen veriler üzerinden hesaplanan güvenirlik katsayıları Tablo 6'da verilmiştir.

Tablo 6: İletişim Becerileri Ölçeğinin Geneli ve Alt Faktörlerine Ait Cronbach Alpha Güvenirlik Sonuçları

\begin{tabular}{cccc}
\hline & İletişim Davranış & İletişim Tutum & İletişim Becerisi \\
\hline Madde Sayıs & 5 & 3 & 8 \\
\hline Cronbach $\alpha$ &, 85 &, 76 &, 85 \\
\hline
\end{tabular}


Tablo 6 incelediğinde ölçeğin doğrulayıcı faktör analizi yapılarak, güvenirlik için Cronbach alpha iç tutarlılık katsayısı hesaplanmıştır. Birinci faktör 0,85 , ikinci faktör 0,76 ve ölçeğin geneline ait güvenirlik katsayısı 0,85 olarak hesaplanmıştır. Özdamar (1999)'a göre belirlenen kriterler dikkate alındığında ölçeğin geneli ve iletişim davranış alt faktörü bağlamında yüksek düzeyde olduğu ve iletişim tutum alt faktörüne ait güvenirliğin kabul edilebilir düzeyde olduğu görülmektedir.

\section{Yaratıcılık ve İnovasyon Becerileri Ölçeğinin Geçerlik ve Güvenirlik Analizi}

Lise düzeyinde öğrenim gören 331 kişilik çalışma grubuna uygulanarak 2 faktörlü olmak üzere birinci faktöründe faaliyetlere ait davranış sıklıklarını ölçen 5 madde ve ikinci faktöründe tutumlarını ifade eden 3 madde olmak üzere 8 maddelik 2 faktörlü yapının doğrulanıp doğrulanmadığ 1 kontrol edilmeye çalışılmıştır. DFA modeline göre 2 faktörlü ve 8 maddelik yapıda uyumsuz hiçbir maddenin olmadığ 1 maddelerin $t$ uyum istatistikleri incelenerek bu sonuca ulaşılmıştır. Uyum göstergelerine ilişkin veriler Tablo 7'de verilmektedir.

Tablo 7: Yaratıcılık ve İnovasyon Becerileri Ölçeğinin Geçerlik Çalışmasına İlişkin Uyum İndeks Değerleri

\begin{tabular}{llllllll}
\hline \multirow{2}{*}{ Uyum İndeks } & $\chi^{2 /(\mathrm{df})}$ & RMSEA & TLI/NNFI & CFI & NFI & AGFI & GFI \\
\cline { 2 - 7 } & $50,08 /(17)=2,95$ & 0.077 & 0.95 & 0.97 & 0.95 & 0,92 & 0,96 \\
\hline Uyum Ölçütleri & Kabul & Kabul & Kabul & Kabul & İyi & İyi & İyi \\
\hline
\end{tabular}

Tablo 7'de yaratıcılık ve inovasyon becerileri ölçeğinin 1. Düzey 2 faktörlü 8 maddelik ölçme modelinin uyum indeks sonuçları ele alınmış ve Ki-Kare değeri $2<\chi 2 /(\mathrm{df})=1,98 \leq 3$ kritik veri aralığında olduğu görülmüsstür. Bu sonuca göre kabul edilebilir uyum verdiği ifade edilebilir. Elde edilen RMSEA değerinin 0.08 ölçüt değerin altında olduğundan dolayı uyum indeksinin kabul edilebilir olduğunu gösterir. Uyum indeks değerleri olan CFI, GFI ve AGFI'nın elde edilen değerleri ile Şekil-1'de verilen ölçüt kriter değerler ile karşılaş̧tırarak incelendiğinde iyi bir uyum sağladığı, TLI ve NFI değerlerinin kritik değerler ile karşılaştırıldığında kabul edilebilir uyum sergiledikleri görülmektedir söylenebilir(Schermelleh vd. 2003:32). "Yaratıc1lı ve İnovasyon Becerileri Ölçeği”ne ait 1. Düzey 2 faktörlü DFA modeli Şekil 5 'te görülmektedir. 


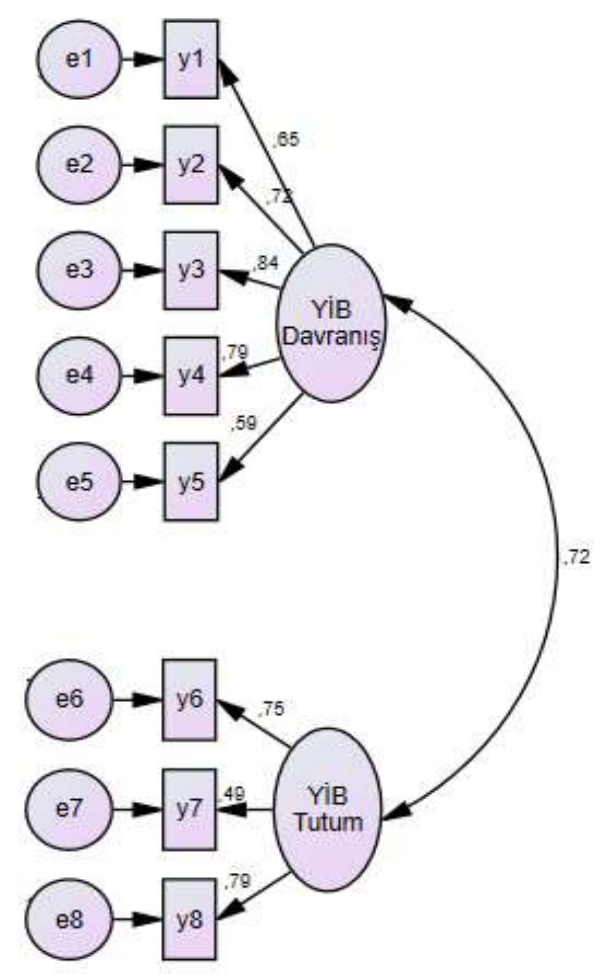

Şekil 5: Yaratıcıllk ve İnovasyon Becerileri Ölçeğine İlişkin Kurulan 1. Düzey 2. Faktörlü DFA Modeli

Yaratıcılık ve İnovasyon Becerileri Ölçeğine ait iki alt faktörü ve ölçeğin geneline ilişkin uygulama yapılan örneklemden elde edilen veriler üzerinden hesaplanan güvenirlik katsayıları Tablo8'de verilmiştir.

Tablo 8: Yaratıcılık ve İnovasyon Becerileri Ölçeğinin Geneli ve Alt Faktörlerine Ait Cronbach Alpha Güvenirlik Sonuçları

\begin{tabular}{lccc}
\hline & $\begin{array}{c}\text { Yaratıcılık ve } \\
\text { İnovasyon Davranış }\end{array}$ & $\begin{array}{c}\text { Yaratıcılık ve İnovasyon } \\
\text { Tutum }\end{array}$ & $\begin{array}{c}\text { Yaratıcılık ve İnovasyon } \\
\text { Becerileri }\end{array}$ \\
\hline Madde Sayıs1 & 5 & 3 & 8 \\
\hline Cronbach $\alpha$ &, 84 &, 73 &, 86 \\
\hline
\end{tabular}

Tablo 8 incelediğinde ölçeğin doğrulayıcı faktör analizi yapılarak, güvenirlik için Cronbach alpha iç tutarlılık katsayısı hesaplanmıştır. Birinci faktör 0,84, ikinci faktör 0,73 ve ölçeğin geneline ait güvenirlik katsayısı 0,86 olarak hesaplanmıştır. Özdamar (1999)'a göre belirlenen kriterler dikkate alındığında ölçeğin geneli ve yaratıcılık ve inovasyon davranış alt faktörü bağlamında yüksek düzeyde olduğu ve yaratıcılık ve inovasyon tutum alt faktörüne ait güvenirliğin kabul edilebilir düzeyde olduğu görülmektedir.

\section{Özyönelim Becerileri Ölçeğinin Geçerlik ve Güvenirlik Analizi}

Lise düzeyinde öğrenim gören 331 kişilik çalışma grubuna uygulanarak 2 faktörlü olmak üzere birinci faktöründe faaliyetlere ait davranış sıklıklarını ölçen 7 madde ve ikinci faktöründe tutumlarını ifade eden 3 madde olmak üzere 10 maddelik 2 faktörlü yapının doğrulanıp doğrulanmadığı kontrol edilmeye çalışılmıştır. DFA modeline göre 2 faktörlü ve 10 maddelik yapıda uyumsuz hiçbir maddenin olmadığı maddelerin $\mathrm{t}$ uyum istatistikleri incelenerek bu sonuca ulaşılmıştır. Uyum göstergelerine ilişkin veriler Tablo9'da verilmektedir. 
Tablo 9: Özyönelim Becerileri Ölçeğinin Geçerlik Çalışmasına İlişkin Uyum İndeks Değerleri

\begin{tabular}{|c|c|c|c|c|c|c|c|}
\hline \multirow{2}{*}{ Uyum İndeks } & $\chi^{2 /(\mathrm{df})}$ & RMSEA & TLI/NNFI & CFI & NFI & AGFI & GFI \\
\hline & $58,66 /(31)=1,89$ & 0.052 & 0.97 & 0.98 & 0.96 & 0,94 & 0,97 \\
\hline Uyum Ölçütleri & $\begin{array}{l}\text { İyi } \\
\end{array}$ & Kabul & İyi & İyi & $\begin{array}{l}\text { İyi } \\
\end{array}$ & $\begin{array}{l}\text { İyi } \\
\end{array}$ & \begin{tabular}{|l|l} 
İyi \\
\end{tabular} \\
\hline
\end{tabular}

Tablo 9'da işbirliği becerileri ölçeğinin 1. Düzey 2 faktörlü 9 maddelik ölçme modelinin uyum indeks sonuçları ele alınmış ve Ki-Kare değeri $0 \leq \chi 2 /(\mathrm{df})=1,89 \leq 2$ kritik veri aralığında olduğu görülmüştür. Bu sonuca göre kabul edilebilir uyum verdiği ifade edilebilir. Elde edilen RMSEA değerinin 0.08 ölçüt değerin altında olduğundan dolayı uyum indeksinin kabul edilebilir olduğunu gösterir Uyum indeks değerleri olan TLI, NFI, CFI, GFI ve AGFI'nın elde edilen değerleri ile Şekil1'de verilen ölçüt kriter değerler ile karşılaş̧ırarak incelendiğinde iyi bir uyum sağladığı söylenebilir(Schermelleh vd. 2003:32). "Özyönelim Becerileri Ölçeği”ne ait 1. Düzey 2 faktörlü DFA modeli Şekil 6'da görülmektedir.

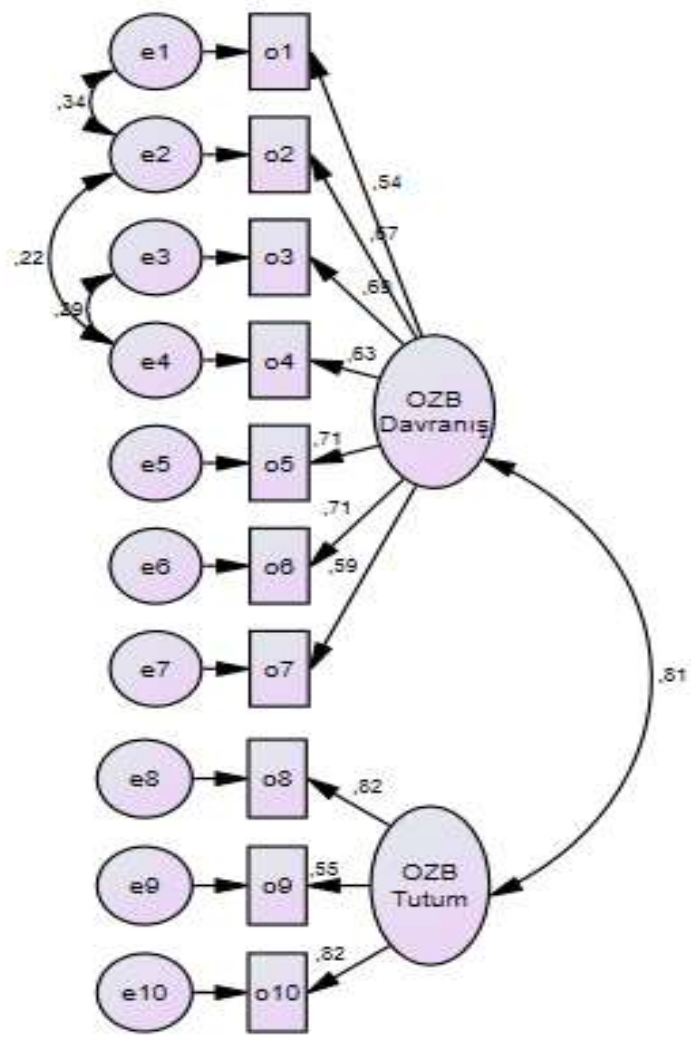

Şekil 6: Özyönelim Becerileri Ölçeğine İlişkin Kurulan 1. Düzey 2. Faktörlü DFA Modeli

Özyönelim Becerileri Ölçeğine ait iki alt faktörü ve ölçeğin geneline ilişkin uygulama yapılan örneklemden elde edilen veriler üzerinden hesaplanan güvenirlik katsayıları Tablo10'da verilmişstir.

Tablo 10: Özyönelim Becerileri Ölçeğinin Geneli ve Alt Faktörlerine Ait Cronbach Alpha Güvenirlik Sonuçları

\begin{tabular}{lccc}
\hline & Özyönelim Davranış & Özyönelim Tutum & Özyönelim Becerileri \\
\hline Madde Sayıs1 & 7 & 3 & 10 \\
\hline Cronbach $\alpha$ &, 85 &, 77 &, 88 \\
\hline
\end{tabular}


Tablo 10 incelediğinde ölçeğin doğrulayıcı faktör analizi yapılarak, güvenirlik için Cronbach alpha iç tutarlılık katsayısı hesaplanmıştır. Birinci faktör 0,85 , ikinci faktör 0,77 ve ölçeğin geneline ait güvenirlik katsayısı 0,88 olarak hesaplanmıştır. Özdamar (1999)'a göre belirlenen kriterler dikkate alındığında ölçeğin geneline ve özyönelim davranış alt faktörüne ilişkin yüksek düzeyde güvenirliğe sahip olduğu ve özyönelim tutum alt faktörüne ilişkin kabul edilebilir düzeyde güvenilir olduğu görülmektedir.

\section{Küresel Bağlantılar Ölçeğinin Geçerlik ve Güvenirlik Analizi}

Lise düzeyinde öğrenim gören 331 kişilik çalışma grubuna uygulanarak 2 faktörlü olmak üzere birinci faktöründe faaliyetlere ait davranış sıklıklarını ölçen 6 madde ve ikinci faktöründe tutumlarını ifade eden 3 madde olmak üzere 9 maddelik 2 faktörlü yapının doğrulanıp doğrulanmadığı kontrol edilmeye çalışılmıştır. DFA modeline göre 2 faktörlü ve 9 maddelik yapıda uyumsuz hiçbir maddenin olmadığı maddelerin $t$ uyum istatistikleri incelenerek bu sonuca ulaşılmıştır. Uyum göstergelerine ilişkin veriler Tablo11'de verilmektedir.

Tablo 11: Küresel Bağlantılar Ölçeğinin Geçerlik Çalışmasına İlişsin Uyum İndeks Değerleri

\begin{tabular}{llllllll}
\hline \multirow{2}{*}{ Uyum İndeks } & $\chi^{2 /(\mathrm{df})}$ & RMSEA & TLI/NNFI & CFI & NFI & AGFI & GFI \\
\cline { 2 - 8 } & $56,02 /(25)=2.24$ & 0.061 & 0.97 & 0.98 & 0.97 & 0,93 & 0,96 \\
\hline Uyum Ölçütleri & Kabul & Kabul & İyi & İyi & İyi & İyi & İyi \\
\hline
\end{tabular}

Tablo 11'de küresel bağlantılar ölçeğinin 1. Düzey 2 faktörlü 9 maddelik ölçme modelinin uyum indeks sonuçları ele alınmış ve Ki-Kare değeri $2<\chi 2 /(\mathrm{df})=2.24 \leq 3$ kritik veri aralığında olduğu görülmüştür. $\mathrm{Bu}$ sonuca göre kabul edilebilir uyum verdiği ifade edilebilir. Elde edilen RMSEA değerinin 0.08 ölçüt değerin altında olduğundan dolayı uyum indeksinin kabul edilebilir olduğunu gösterir. Uyum indeks değerleri olan TLI, NFI, CFI, GFI ve AGFI'nın elde edilen değerleri ile Şekil1 'de verilen ölçüt kriter değerler ile karşılaştırarak incelendiğinde iyi bir uyum sağladığ söylenebilir (Schermelleh vd. 2003:32). "Küresel Bağlantılar Ölçeği”ne ait 1. Düzey 2 faktörlü DFA modeli Şekil7'de görülmektedir. 


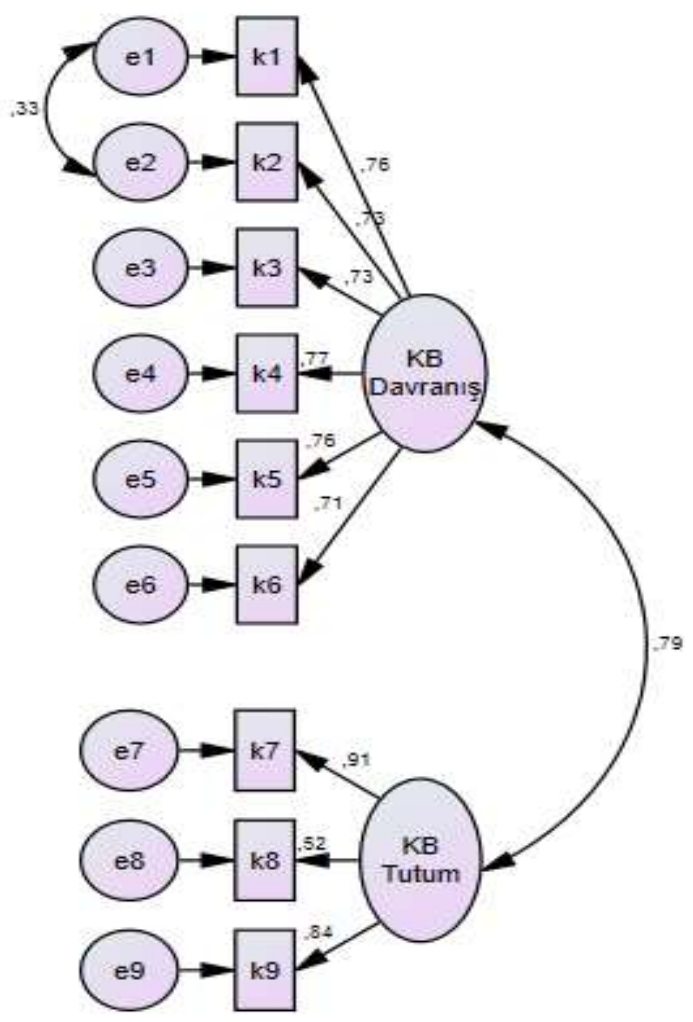

Şekil 7: Küresel Bağlantılar Ölçeğine İlişkin Kurulan 1. Düzey 2. Faktörlü DFA Modeli

Küresel Bağlantılar Ölçeğine ait iki alt faktörü ve ölçeğin geneline ilişkin uygulama yapılan örneklemden elde edilen veriler üzerinden hesaplanan güvenirlik katsayıları Tablo12'de verilmiştir.

Tablo 12: Küresel Bağlantılar Ölçeğinin Geneli ve Alt Faktörlerine Ait Cronbach Alpha Güvenirlik Sonuçları

\begin{tabular}{llll}
\hline & Küresel Davranış & Küresel Tutum & Küresel Bağlantılar \\
\hline Madde Sayısı & 6 & 3 & 9 \\
\hline Cronbach $\alpha$ &, 87 &, 81 &, 89 \\
\hline
\end{tabular}

Tablo 12 incelediğinde ölçeğin doğrulayıcı faktör analizi yapılarak, güvenirlik için Cronbach alpha iç tutarlılık katsayısı hesaplanmıştır. Birinci faktör 0,87 , ikinci faktör 0,81 ve ölçeğin geneline ait güvenirlik katsayısı 0,89 olarak hesaplanmıştır. Özdamar (1999)'a göre belirlenen kriterler dikkate alındığında ölçeğin geneli ve alt faktörleri bağlamında yüksek düzeyde olduğu görülmektedir.

\section{Yerel Bağlantılar Ölçeğinin Geçerlik ve Güvenirlik Analizi}

Lise düzeyinde öğrenim gören 331 kişilik çalışma grubuna uygulanarak 2 faktörlü olmak üzere birinci faktöründe faaliyetlere ait davranış sıklıklarını ölçen 5 madde ve ikinci faktöründe tutumlarını ifade eden 3 madde olmak üzere 8 maddelik 2 faktörlü yapının doğrulanıp doğrulanmadığı kontrol edilmeye çalışılmıştır. DFA modeline göre 2 faktörlü ve 8 maddelik yapıda uyumsuz hiçbir maddenin olmadığ 1 maddelerin $\mathrm{t}$ uyum istatistikleri incelenerek bu sonuca ulaşılmıştır. Uyum göstergelerine ilişkin veriler Tablo13'de verilmektedir. 
Tablo 13: Yerel Bağlantılar Ölçeğinin Geçerlik Çalışmasına İlişkin Uyum İndeks Değerleri

\begin{tabular}{llllllll}
\hline \multirow{2}{*}{ Uyum İndeks } & $\chi^{2 /(\mathrm{df})}$ & RMSEA & TLI/NNFI & CFI & NFI & AGFI & GFI \\
\cline { 2 - 7 } & $40,55 /(17)=2.39$ & 0.065 & 0.97 & 0.98 & 0.97 & 0,94 & 0,97 \\
\hline Uyum Ölçütleri & Kabul & Kabul & İyi & İyi & İyi & İyi & İyi \\
\hline
\end{tabular}

Tablo 13’te yerel bağlantılar ölçeğinin 1. Düzey 2 faktörlü 8 maddelik ölçme modelinin uyum indeks sonuçları ele alınmış ve Ki-Kare değeri $2<\chi 2 /(\mathrm{df})=2.39 \leq 3$ kritik veri aralığında olduğu görülmüştür. Bu sonuca göre kabul edilebilir uyum verdiği ifade edilebilir. Elde edilen RMSEA değerinin 0.08 ölçüt değerin altında olduğundan dolayı uyum indeksinin kabul edilebilir olduğunu gösterir. Uyum indeks değerleri olan TLI, NFI, CFI, GFI ve AGFI'nın elde edilen değerleri ile Şekil1'de verilen ölçüt kriter değerler ile karşılaştırarak incelendiğinde iyi bir uyum sağladığı söylenebilir(Schermelleh vd. 2003:32). "Yerel Bağlantılar Ölçeği”ne ait 1. Düzey 2 faktörlü DFA modeli Şekil-8'de görülmektedir.

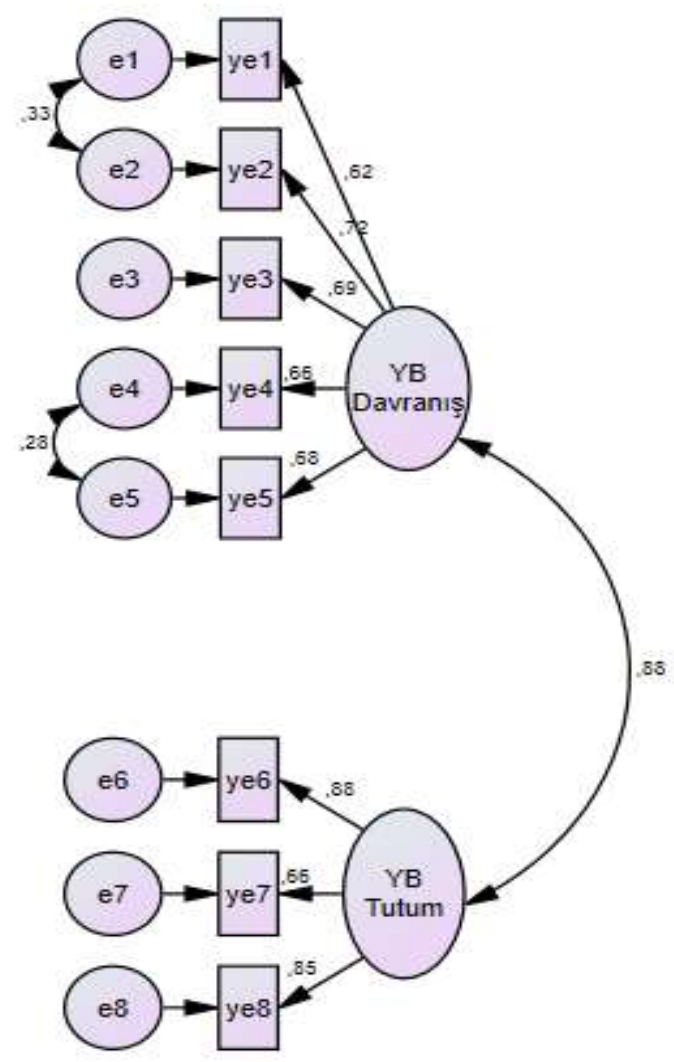

Şekil 8: Yerel Bağlantılar Ölçeğine İlişkin Kurulan 1. Düzey 2. Faktörlü DFA Modeli

Yerel Bağlantılar Ölçeğine ait iki alt faktörü ve ölçeğin geneline ilişkin uygulama yapılan örneklemden elde edilen veriler üzerinden hesaplanan güvenirlik katsayıları Tablo14'de verilmiştir.

Tablo 14: Yerel Bağlantılar Ölçeğinin Geneli ve Alt Faktörlerine Ait Cronbach Alpha Güvenirlik Sonuçları

\begin{tabular}{llll}
\hline & Küresel Davranış & Küresel Tutum & Küresel Bağlantılar \\
\hline Madde SayıS1 & 5 & 3 & 8 \\
\hline Cronbach $\alpha$ &, 82 &, 83 &, 89 \\
\hline
\end{tabular}


Tablo 14 incelediğinde ölçeğin doğrulayıcı faktör analizi yapılarak, güvenirlik için Cronbach alpha iç tutarlılık katsayısı hesaplanmıştır. Birinci faktör 0,82 , ikinci faktör 0,83 ve ölçeğin geneline ait güvenirlik katsayısı 0,89 olarak hesaplanmıştır. Özdamar (1999)'a göre belirlenen kriterler dikkate alındığında ölçeğin geneli ve alt faktörleri bağlamında yüksek düzeyde olduğu görülmektedir.

\section{Analizi}

Teknolojiyi Öğrenmeyi Bir Araç Olarak Kullanma Ölçeğinin Geçerlik ve Güvenirlik

Lise düzeyinde öğrenim gören 331 kişilik çalışma grubuna uygulanarak 2 faktörlü olmak üzere birinci faktöründe faaliyetlere ait davranış sıklıklarını ölçen 8 madde ve ikinci faktöründe tutumlarını ifade eden 3 madde olmak üzere 11 maddelik 2 faktörlü yapının doğrulanıp doğrulanmadığ 1 kontrol edilmeye çalışılmıştır. DFA modeline göre 2 faktörlü ve 11 maddelik yapıda uyumsuz hiçbir maddenin olmadığı maddelerin $\mathrm{t}$ uyum istatistikleri incelenerek bu sonuca ulaşılmıştır. Uyum göstergelerine ilişkin veriler Tablo15'de verilmektedir.

Tablo 15: Teknolojiyi Bir Araç Olarak Kullanma Ölçeğinin Geçerlik Çalışmasına İlişkin Uyum İndeks Değerleri

\begin{tabular}{llllllll}
\hline \multirow{2}{*}{ Uyum İndeks } & $\chi 2 /(\mathrm{df})$ & RMSEA & TLI/NNFI & CFI & NFI & AGFI & GFI \\
\cline { 2 - 7 } & $93,54 /(38)=2,46$ & 0.067 & 0.96 & 0.97 & 0.95 & 0,92 & 0,95 \\
\hline Uyum Ölçütleri & Kabul & Kabul & Kabul & İyi & İyi & İyi & İyi \\
\hline
\end{tabular}

Tablo 15' te teknolojiyi bir araç olarak kullanma ölçeğinin 1 . Düzey 2 faktörlü 11 maddelik ölçme modelinin uyum indeks sonuçları ele alınmış ve Ki-Kare değeri $2<\chi 2 /(\mathrm{df})=2,46 \leq 3$ kritik veri aralığında olduğu görülmüsstür. Bu sonuca göre kabul edilebilir uyum verdiği ifade edilebilir. Elde edilen RMSEA değerinin 0.08 ölçüt değerin altında olduğundan dolayı uyum indeksinin kabul edilebilir olduğunu gösterir. NFI, CFI, GFI ve AGFI değerlerinin kritik değerler ile karşılaştırıldığında iyi uyum sergiledikleri, TLI değeri kritik değer ile karşılaştırıldığında kabul edilebilir uyum sergilediği görülmektedir(Schermelleh vd. 2003:32). "Teknolojiyi Bir Araç Olarak Kullanma Ölçeği”ne ait 1. Düzey 2 faktörlü DFA modeli Şekil-9'da görülmektedir. 


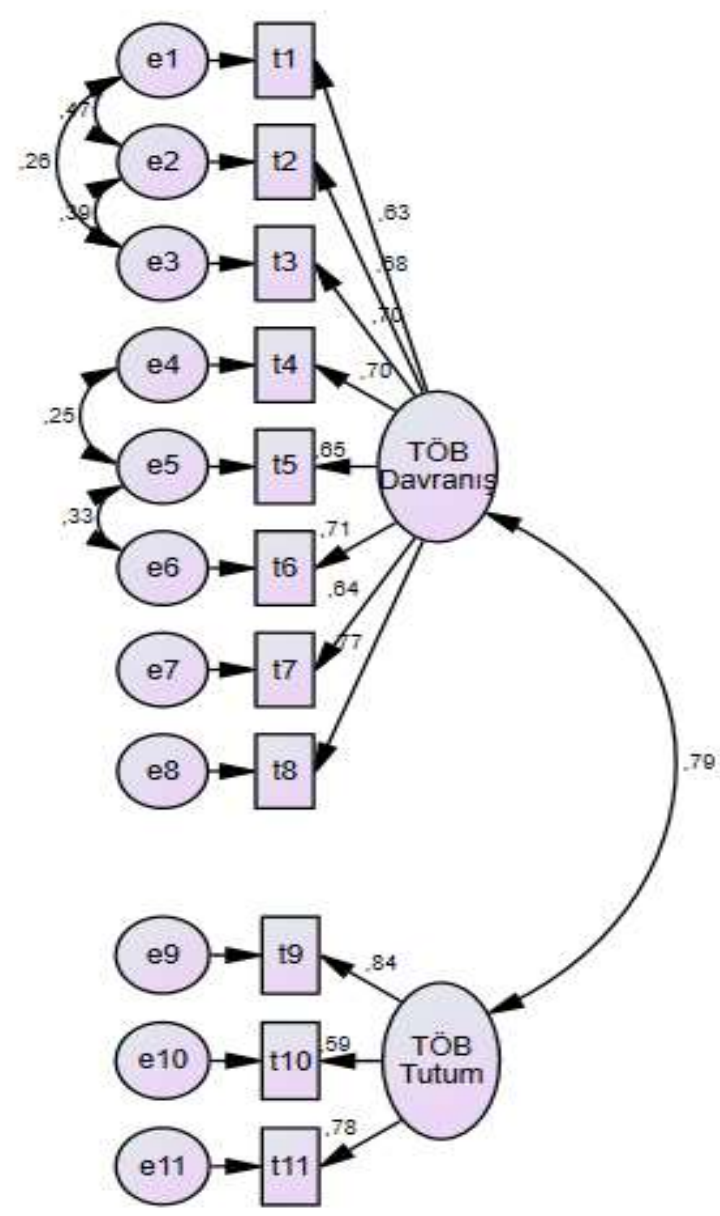

Şekil 9: Teknolojiyi Bir Araç Olarak Kullanma Ölçeğine İlişsin Kurulan 1. Düzey 2. Faktörlü DFA Modeli

Teknolojiyi Bir Araç Olarak Kullanma Ölçeğine ait iki alt faktörü ve ölçeğin geneline ilişkin uygulama yapılan örneklemden elde edilen veriler üzerinden hesaplanan güvenirlik katsayıları Tablo16' da verilmiştir.

Tablo 16: Teknolojiyi Bir Araç Olarak Kullanma Ölçeğinin Geneli ve Alt Faktörlerine Ait Cronbach Alpha Güvenirlik Sonuçları

\begin{tabular}{|c|c|c|c|c|c|}
\hline & $\begin{array}{l}\text { Teknoloji } \\
\text { Davranış }\end{array}$ & Teknoloji Tutum & $\begin{array}{l}\text { Teknolojiyi Bir } \\
\text { Kullanma }\end{array}$ & Araç & Olarak \\
\hline Madde Sayıs1 & 8 & 3 & 11 & & \\
\hline Cronbach $\alpha$ & 89 & ,78 & 90 & & \\
\hline
\end{tabular}

Tablo 16 incelediğinde ölçeğin doğrulayıcı faktör analizi yapılarak, güvenirlik için Cronbach alpha iç tutarlılık katsayısı hesaplanmıştır. Birinci faktör 0,89 , ikinci faktör 0,78 ve ölçeğin geneline ait güvenirlik katsayısı 0,90 olarak hesaplanmıştır. Özdamar(1999)'a göre belirlenen kriterler dikkate alındığında ölçeğin geneline ve teknoloji davranış alt faktörüne ilişkin yüksek düzeyde güvenirliğe sahip olduğu ve teknoloji tutum alt faktörüne ilişkin kabul edilebilir düzeyde güvenilir olduğu görülmektedir. 


\section{Sonuç}

Bu çalışmada öğrenciler için 21. yüzyıl becerilerini öğrenmelerine belirlemek amaciyla bir ölçek geliştirilmiştir. Ölçek 73 maddeden oluşmakta, beş basamaklı likert tipi bir ölçektir. Her biri iki faktörlü olan 8 alt ölçek tasarlanmıştır. Faktörlerde yer alan maddelerin her biri; nadiren(1), Ara Sıra(2), Orta Ölçüde(3), Büyük Ölçüde(4), Çok Büyük Ölçüde(5) olmak üzere derecelendirilmiştir. Ölçeğin tüm maddeleri olumlu olduğu için ters puanlama yoluna gidilmemiştir.

Faktör analizi(1) ve ayırt edicilik(2) özellikleri incelenerek ölçeğin geçerliği test edilmiştir. Doğrulayıcı faktör analizi teknikleri kullanılarak elde edilen sonuçlarına göre; ölçek iki alt ve sekiz ana faktörden oluşmaktadır. Faktörlerdeki maddelerin faktör yükleri, öz değerleri ve açıklanan varyans oranları dikkate alınarak yapı geçerliğine sahip bir ölçek olduğu söylenebilir.

Hem birincil hem de ikincil doğrulayıcı faktör analizi sonuçlarına göre ölçek modelinin gözlenen değerleri, verinin kabul edilebilir uyum gösterdiği; bir başka ifade ile elde edilen bu modelin veri tarafından doğrulandığı yapılan doğrulayıcı faktör analizi sonucunda görülmüştür.

Konuya ilişkin alan yazın taraması gerçekleştirilmiş; içerik ve amaç yönüyle benzer bir ölçeğe rastlanılmadığından benzer ölçekler geçerliliği hesaplanamamıştır.

Ölçeğin iç tutarlığı için iki eş yarı korelasyonu; Cronbach Alpha güvenirlik katsayıları incelenmiştir. Elde edilen değerler çerçevesinde ölçeğin hem faktörler hem de geneli için güvenilir ölçümler yapabildiği söylenebilir. Sonuç olarak ölçeğinin, lise öğrencilerinin tutumlarının belirlenmesinde kullanılabilecek geçerli ve güvenilir bir ölçek olduğu söylenebilir. Bu ölçek tekrar düzenlenerek lisans öğrencilerine de uygulanabilir.

$\mathrm{Bu}$ çalışma, mevcut diğer araştırmalara dayanan 21. yüzyıla ait becerilerin bir listesini belirledi, öğrencilere en sık ve kapsamlı olarak hangi becerileri öğretildiğini, Öğrenciler genellikle becerilerini geliştirmeye çalıştıklarını, en azından bu becerileri etkili bir şekilde değerlendirebildiklerini belirtmişlerdir. Son olarak, bu çalışma, 21. yüzyıl becerilerinin öğretilmesi üzerine gelecekteki araştırmalar için anket araçlarının geliştirilmesinde yardımcı olabilir.

\section{Kaynakça}

Özdamar, K. (1999). Paket programlar ile istatistiksel veri analiz. Kaan Kitabevi.

Schermelleh-Engel, K., Moosbrugger, H., \& Müller, H. (2003). Evaluating the fit of structural equation models: Tests of significance and descriptive goodness-of-fit measures. Methods of psychological research online, 8(2), 23-74.

Shear, L., Novais, G., Means, B., Gallagher, L., \& Langworthy, M. (2010). ITL research design. Menlo Park, CA: SRI International. Retrieved from https://www.sri.com/wpcontent/uploads/pdf/itl_research_design_15_nov_2010.pdf.

Ery1lmaz S., Uluyol Ç. (2015). Evaluation Of FATIH Project In The Consideration Of 21st Century Skills. GUIGEF, 35(2), 209-229. (Kontrol No: 1738022).

Hixson, N.K., Ravitz, J., \& Whisman, A. (2012). Extended professional development in projectbased learning: Impacts on 21 st century teaching and student achievement. Charleston, $W V$ : West Virginia Department of Education, Division of Teaching and Learn-ing, Office of Research.

Şimşek ÖF. Yapısal Eşitlik Modellemesine Giriş, Temel İlkeler ve LiSREL Uygulamaları. Ekinoks; 2007. s. 4-22. 
The William and Flora Hewlett Foundation (2010). Education program strategic plan. Menlo Park, CA: Author. Retrieved from http://www.hewlett.org/uploads/documents/ Education_Strategic_Plan_201.pdf

West Virginia Board of Education (2008). 21st century learning skills and technology tools con-tent standards and objectives for West Virginia schools. (Policy 2520.14). Charleston, WV: Author. Retrieved from http://wvde.state.wv.us/policies/ p2520.14.pdf

West Virginia Department of Education. (n.d.) Office of Instruction website. Charleston, WV: author.

Ek-1 : Öğrenciler İçin 21. Yüzyıl Öğrenme Becerileri Veri Toplama Aracı

\section{ELEŞTIREL (KRITTIK -ÖNEMLI) DÜŞÜNME BECERISİ}

1. Sınıf içerisinde öğrenme faaliyetlerini gerçekleştirirken hangi sıklıkla aşağıdaki davranışları yaparsınız?

a. Ödevlerimi tamamlamadan önce farklı kaynaklardan karşılaştırma yaparım.

b. Bulduğum sonuçları sayı analizleri, örnek olaylar veya ilgili bilgilerle ilişkilendiririm.

c. Okuduklarımı, öğrendiklerinizi özetleyin ya da kendi cümlelerinizle yorumlarım.

d. Rakip argümanları, perspektifleri ya da problem çözümlerini analiz ederim.

e. Destekleyici kanıtlara veya muhakeme temelli ikna edici bir argüman geliştiririm.

f. Tekbir doğru cevabı ya da çözümü olmayan soruları ya da karmaşık olan soruları çözerim.

\begin{tabular}{ccccc} 
Nadiren & Ara sıra & $\begin{array}{c}\text { Orta } \\
\text { ölçüde }\end{array}$ & $\begin{array}{c}\text { Büyük } \\
\text { ölçüde }\end{array}$ & $\begin{array}{c}\text { Çok } \\
\text { büyük } \\
\text { ölçüde }\end{array}$ \\
O & O & O & O & O \\
O & O & O & O & O \\
O & O & O & O & O \\
O & O & O & O & O \\
O & O & O & O & O \\
O & O & O & O & O \\
& & & & Çok \\
bäyük \\
Nadiren & Ara sıra & ölçüde & ölçüde & ölçïde \\
O & O & O & O & O \\
O & O & O & O & O \\
O & O & O & O & O \\
& & & & \\
\hline & & & &
\end{tabular}

\begin{tabular}{|c|c|c|c|c|c|}
\hline $\begin{array}{l}\text { 1. Sınıf içerisinde öğrenme faaliyetlerini gerçekleştirirken hangi sıklıkla } \\
\text { aşağıdaki davranışları yapmak istersiniz? }\end{array}$ & Nadiren & Ara sira & $\begin{array}{l}\text { Orta } \\
\text { ölçüide }\end{array}$ & $\begin{array}{l}\text { Büyük } \\
\text { ölçüde }\end{array}$ & $\begin{array}{c}\text { Çok } \\
\text { büyük } \\
\text { ölçüde }\end{array}$ \\
\hline a. Görevleri tamamlamak için çiftler ya da küçük gruplar halinde çalışırım. & $\mathrm{O}$ & $\mathrm{O}$ & $\mathrm{O}$ & $\mathrm{O}$ & $\mathrm{O}$ \\
\hline $\begin{array}{l}\text { b. Hedeflerimi belirlemek ya da planını oluşturmak için diğer öğrencilerle } \\
\text { çalışırım. }\end{array}$ & $\mathrm{O}$ & $\mathrm{O}$ & $\mathrm{O}$ & $\mathrm{O}$ & $\mathrm{O}$ \\
\hline c. Her öğrencinin katkılarıyla ortak ürünler oluştururum. & $\mathrm{O}$ & $\mathrm{O}$ & $\mathrm{O}$ & $\mathrm{O}$ & $\mathrm{O}$ \\
\hline d. Grup çalışmasını sınıfa, öğretmene veya diğerlerine sunarım. & $\mathrm{O}$ & $\mathrm{O}$ & $\mathrm{O}$ & $\mathrm{O}$ & $\mathrm{O}$ \\
\hline e. Grup çalışmalarında takım olarak çalışarak geri bildirim oluştururum. & $\mathrm{O}$ & $\mathrm{O}$ & $\mathrm{O}$ & $\mathrm{O}$ & $\mathrm{O}$ \\
\hline $\begin{array}{l}\text { f. Arkadaşlarıma geri bildirim verir veya diğer öğrencilerin çalışmalarını } \\
\text { değerlendiririm. }\end{array}$ & $\mathrm{O}$ & $\mathrm{O}$ & $\mathrm{O}$ & $\mathrm{O}$ & $\mathrm{O}$ \\
\hline . Sınıfınız hakkında aşağıdaki beyanlara hangi ölçüde katılıyorsunuz? & Nadiren & Ara sira & $\begin{array}{l}\text { Orta } \\
\text { ölçüde }\end{array}$ & $\begin{array}{l}\text { Büyük } \\
\text { ölçüde }\end{array}$ & $\begin{array}{c}\text { Çok } \\
\text { büyük } \\
\text { ölçüde }\end{array}$ \\
\hline a. İşbirliği becerilerimi geliştirmeye çalışırım. & $\mathrm{O}$ & $\mathrm{O}$ & $\mathrm{O}$ & $\mathrm{O}$ & $\mathrm{O}$ \\
\hline b. Çoğu arkadaşım sınıfta iken işbirliği becerileri öğrenir. & $\mathrm{O}$ & $\mathrm{O}$ & $\mathrm{O}$ & $\mathrm{O}$ & $\mathrm{O}$ \\
\hline c. İşbirliği becerilerimi etkili bir şekilde değerlendiririm. & $\mathrm{O}$ & $\mathrm{O}$ & $\mathrm{O}$ & $\mathrm{O}$ & $\mathrm{O}$ \\
\hline
\end{tabular}


1. Sınıf içerisinde öğrenme faaliyetlerini gerçekleştirirken hangi sıklıkla aşağıdaki davranışları yapmak istersiniz?

a. Yapı verilerini yazılı ürünler veya sözlü sunumlar (örneğin, çizelgeler, tablolar veya grafikler oluşturma) için kullanırım.

b. Fikirlerimi yazılı bir kağıttan başka medya (ör. Posterler, videolar, bloglar, vb.) kullanarak iletirim.

c. Öğretmene veya başkalarına sözlü bir sunum hazırlar ve sunarım.

d. Soruları bir kitle önünde cevaplarım.

e. Çalışmalarımı nasıl sunacağıma veya öğrenmelerimi nasıl göstereceğime karar veririm.

$\begin{array}{ccccc}\text { Nadiren } & \text { Ara sıra } & \begin{array}{c}\text { Orta } \\ \text { ölçüde }\end{array} & \begin{array}{c}\text { Büyük } \\ \text { ölçüde }\end{array} & \begin{array}{c}\text { Çok } \\ \text { büyük } \\ \text { ölçüde }\end{array} \\ \text { O } & \text { O } & \text { O } & \text { O } & \text { O } \\ \text { O } & \text { O } & \text { O } & \text { O } & \text { O } \\ \text { O } & \text { O } & \text { O } & \text { O } & \text { O } \\ \text { O } & \text { O } & \text { O } & \text { O } & \text { O } \\ \text { O } & \text { O } & \text { O } & \text { O } & \text { O } \\ & & & & \text { Çok } \\ \text { büyük }\end{array}$

\section{YARATICILIK VE İNOVASYON BECERILERI}

1. Sınıf içerisinde öğrenme faaliyetlerini gerçekleştirirken hangi sıklıkla aşağıdaki davranışları yapmak istersiniz?

a. Beyin firtınası veya kavram haritası gibi fikir olușturma tekniklerini kullanırım.

b. Bir sorunun üstesinden gelmek için kendi fikirlerimi üretirim.

c. Farklı fikirleri test eder ve iyileştirmek için çalışırım.

d. Karmaşık ve açık uçlu bir soruna bir çözüm bulurum.

e. Fikirlerimi ifade etmek için orijinal bir ürün veya performans yaratırım.

\begin{tabular}{|c|c|c|c|c|}
\hline Nadiren & Ara sıra & $\begin{array}{c}\text { Orta } \\
\text { ölçüde }\end{array}$ & $\begin{array}{l}\text { Büyüuk } \\
\text { ölçüde }\end{array}$ & $\begin{array}{c}\text { Çok } \\
\text { büyük } \\
\text { ölçüde }\end{array}$ \\
\hline $\mathrm{O}$ & $\mathrm{O}$ & $\mathrm{O}$ & $\mathrm{O}$ & $\mathrm{O}$ \\
\hline $\mathrm{O}$ & $\mathrm{O}$ & $\mathrm{O}$ & $\mathrm{O}$ & $\mathrm{O}$ \\
\hline $\mathrm{O}$ & $\mathrm{O}$ & $\mathrm{O}$ & $\mathrm{O}$ & $\mathrm{O}$ \\
\hline $\mathrm{O}$ & $\mathrm{O}$ & $\mathrm{O}$ & $\mathrm{O}$ & $\mathrm{O}$ \\
\hline $\mathrm{O}$ & $\mathrm{O}$ & $\mathrm{O}$ & $\mathrm{O}$ & $\mathrm{O}$ \\
\hline Nadiren & Ara sıra & $\begin{array}{c}\text { Orta } \\
\text { ölçüde }\end{array}$ & $\begin{array}{l}\text { Büyüik } \\
\text { ölçüde }\end{array}$ & $\begin{array}{c}\text { Çok } \\
\text { büyük } \\
\text { ölçüde }\end{array}$ \\
\hline $\mathrm{O}$ & $\mathrm{O}$ & $\mathrm{O}$ & $\mathrm{O}$ & $\mathrm{O}$ \\
\hline $\mathrm{O}$ & $\mathrm{O}$ & $\mathrm{O}$ & $\mathrm{O}$ & $\mathrm{O}$ \\
\hline $\mathrm{O}$ & $\mathrm{O}$ & $\mathrm{O}$ & $\mathrm{O}$ & $\mathrm{O}$ \\
\hline
\end{tabular}

Sınıfınız hakkında aşağıdaki beyanlara hangi ölçüde katılıyorsunuz?

a. Yaratıcılık ve yenilik becerilerini geliştirmeye çalışırım.

b. Çoğu arkadaşım, ders sırasında yaratıcılık ve yenilik becerilerini öğrenir.

c. Yaratıcılık ve yenilik becerilerini etkili bir şekilde değerlendiririm.
a. Iletişim becerilerimi geliştirmeye çalışırım.
b. Coğu arkadaşım, ders sırasında iletişim becerileri öğrenir.

diren

sira

olçüde

lçüde

iyük

çïde

$\mathrm{O}$ 


\section{ÖZYÖNELIM BECERILLERİ}

1. Sınıf içerisinde öğrenme faaliyetlerini gerçekleștirirken hangi sıklıkla aşağıdaki davranışları yapmak istersiniz?

a. Zor bir soru veya soru ile karşı karşıya kaldığımda insiyatif kullanırım.

b. Kendi öğrenme konularımda takip etmeyi düşündüğüm soruları seçerim.

c. Karmaşık bir görevi gerçekleştirmek için atılacak adımları planlarım.

d. Çalışmak için örnekleri veya kullanılacak kaynakları seçerim.

e. Karmaşık bir görevi tamamlama yönündeki ilerlemelerini izlerim ve çalışmalarımı buna göre değiştiririm.

f. Çalıșmayı tamamlanmadan önce kalitesini değerlendirmek için belirli kriterleri kullanırım.

g. Çalışmalarımı gözden geçirmek için akran, öğretmen veya uzman görüşlerini kullanırım.

2. Sınıfınız hakkında aşağıdaki beyanlara hangi ölçüde katılıyorsunuz? a. Kendi kendini yönlendirme (öz yönelim) becerilerimi geliştirmeye çalışırım.

b. Çoğu arkadaşım, ders sırasında kendi kendini yönlendirme becerilerini öğrenir.

c. Kendi kendine yön verme becerilerini etkili bir şekilde değerlendiririm.

$\begin{array}{ccccc}\text { Nadiren } & \text { Ara sıra } & \begin{array}{c}\text { Orta } \\ \text { ölçüde }\end{array} & \begin{array}{c}\text { Bǜü̈k } \\ \text { ölçüde }\end{array} & \begin{array}{c}\text { büyük } \\ \text { ölçüde }\end{array} \\ \text { O } & \text { O } & \text { O } & \text { O } & \text { O } \\ \text { O } & \text { O } & \text { O } & \text { O } & \text { O } \\ \text { O } & \text { O } & \text { O } & \text { O } & \text { O } \\ \text { O } & \text { O } & \text { O } & \text { O } & \text { O } \\ \text { O } & \text { O } & \text { O } & \text { O } & \text { O } \\ \text { O } & \text { O } & \text { O } & \text { O } & \text { O } \\ \text { O } & \text { O } & \text { O } & \text { O } & \text { O } \\ & & & \text { Çok } \\ \text { Nadiren } & \text { Ara sıra } & \text { ölçüde } & \text { ölçüde } & \text { ölçü̈de } \\ \text { O } & \text { O } & \text { O } & \text { O } & \text { O } \\ \text { O } & \text { O } & \text { O } & \text { O } & \text { O } \\ \text { O } & \text { O } & \text { O } & \text { O } & \text { O }\end{array}$

\section{KÜRESEL BAĞLANTILAR}

1. Sınıf içerisinde öğrenme faaliyetlerini gerçekleştirirken hangi sıklıkla aşağıdaki davranıșları yapmak istersiniz?

a. Diğer ülkeler veya kültürler hakkında bilgi toplarım.

b. Diğer ülkelerdeki veya kültürlerdeki insanlardan gelen bilgileri veya fikirleri kullanırım.

c. Küresel karșılıklı bağımlılık ile ilgili konuları tartışırım (örneğin,

küresel çevre eğilimleri, küresel piyasa ekonomisi).

d. Benliklerinin dışında insanların kültürel yaşamlarını anlamaya çalışırım.

e. Uzak ülkeler coğrafyasını incelerim.

f. Kendi deneyimlerimin ve yerel konuların küresel meselelere nasıl bağlı oldukları üzerine düşünürüm.

$\begin{array}{ccccc}\text { Nadiren } & \text { Ara sıra } & \begin{array}{c}\text { Orta } \\ \text { ölçüde }\end{array} & \begin{array}{c}\text { Büyük } \\ \text { ölçüde }\end{array} & \begin{array}{c}\text { Çok büyük } \\ \text { ölçüde }\end{array} \\ \text { O } & \text { O } & \text { O } & \text { O } & \text { O } \\ \text { O } & \text { O } & \text { O } & \text { O } & \text { O } \\ \text { O } & \text { O } & \text { O } & \text { O } & \text { O } \\ \text { O } & \text { O } & \text { O } & \text { O } & \text { O } \\ \text { O } & \text { O } & \text { O } & \text { O } & \text { O } \\ \text { O } & \text { O } & \text { O } & \text { O } & \text { O } \\ \text { Nadiren } & \text { Ara sıra } & \text { ölçüde } & \text { ölçüde } & \text { ölçüde } \\ \text { O } & \text { O } & \text { O } & \text { O } & \text { O } \\ \text { O } & \text { O } & \text { O } & \text { O } & \text { O } \\ \text { O } & \text { O } & \text { O } & \text { O } & \text { O }\end{array}$

\section{YEREL BAĞLANTILAR}

1. Sınıf içerisinde öğrenme faaliyetlerini gerçekleștirirken hangi sıklıkla aşağıdaki davranışları yapmak istersiniz?

a. Ailem veya topluluğumla alakalı konuları araştırırım.

b. Öğrenmekte olduğum şeyleri yerel durumlara, sorunlara veya problemlere uygularım.

c. Bir sınıf projesi veya etkinliği hakkında topluluğun bir veya daha fazla üyesiyle konuşurum.

d. Farklı paydaş gruplarının veya topluluk üyelerinin bir meseleyi nasıl gördüklerini analiz ederim.

e. Bir soru veya görevi, farklı topluluk üyelerinin veya grupların endișelerini hafifletecek bir şekilde yanıtlarım.

$\begin{array}{ccc}\text { Nadiren } & \text { Ara sira } \\ & \mathrm{O} & \mathrm{O} \\ & \mathrm{O} & \mathrm{O} \\ \text { aha fazla } & \mathrm{O} & \mathrm{O} \\ \text { O nasil } & \mathrm{O} & \mathrm{O} \\ & \mathrm{O} & \mathrm{O}\end{array}$

Nadiren

2. Sınıfınız hakkında aşağıdaki beyanlara hangi ölçüde katılıyorsunuz?

\begin{tabular}{|c|c|c|}
\hline $\begin{array}{c}\text { Orta } \\
\text { ölçüde }\end{array}$ & $\begin{array}{l}\text { Büyüik } \\
\text { ölçüde }\end{array}$ & $\begin{array}{c}\text { Çok } \\
\text { büyük } \\
\text { ölçüde }\end{array}$ \\
\hline $\mathrm{O}$ & $\mathrm{O}$ & $\mathrm{O}$ \\
\hline $\mathrm{O}$ & $\mathrm{O}$ & $\mathrm{O}$ \\
\hline $\mathrm{O}$ & $\mathrm{O}$ & $\mathrm{O}$ \\
\hline $\mathrm{O}$ & $\mathrm{O}$ & $\mathrm{O}$ \\
\hline $\mathrm{O}$ & $\mathrm{O}$ & $\mathrm{O}$ \\
\hline $\begin{array}{c}\text { Orta } \\
\text { ölçüde }\end{array}$ & $\begin{array}{l}\text { Büyülk } \\
\text { ölçüde }\end{array}$ & $\begin{array}{c}\text { Çok } \\
\text { büyüik }\end{array}$ \\
\hline
\end{tabular}


a. Yerel bağlantılar kurma becerilerimi geliştirmeye çalışırım.

b. Çoğu arkadaşım ders sırasında yerel bağlantı kurmayı öğrenir.

c. Yerel bağlantı kurma becerilerini etkili bir şekilde değerlendiririm.

$\mathrm{O}$
$\mathrm{O}$
$\mathrm{O}$

O

$\mathrm{O}$
$\mathrm{O}$

ölçüde

\section{TEKNOLOJIYİ ÖĞRENMEYE BİR ARAÇ OLARAK KULLANMA}

1. Sınıf içerisinde öğrenme faaliyetlerini gerçekleştirirken hangi sıkııkla aşağıdaki davranışları yapmak istersiniz?

a. Kendimi eğitmek için teknoloji veya internet kullanırım (ör. Kahn Akademi veya diğer videolar, ders kitapları, kendi kendine öğrenme amaçlı web siteleri vb.).

b. Bir görevi tamamlamak için uygun teknoloji araçları veya kaynakları seçerim.

c. Çevrimiçi kaynakların güvenilirliğini ve uygunluğunu değerlendiririm. d. Bilgileri analiz etmek için teknolojiyi kullanırım (ör. Veritabanları, elektronik tablolar, grafik programları, vb.).

e. Bilgilerimi paylaşmama yardımcı olması için teknoloji kullanırım (ör. Ses veya video kullanarak sunum yazılımı, bloglar, podcast'ler vb.). f. Ekip çalıșması veya birlikte çalıșmayı desteklemek için (örneğin, paylaşılan çalışma alanları, e-posta alışverişi, geri bildirim alma ve alma vb.) teknolojiyi kullanırım.

g. Uzmanlarla veya yerel / global topluluk üyeleriyle doğrudan etkileşim kurmak için teknolojiyi kullanırım.

h. Genişletilmiş görevler veya görevler üzerindeki çalışmaları takip etmek için teknoloji kullanırım.

2. Sınıfınız hakkında aşağıdaki beyanlara hangi ölçüde katılıyorsunuz? a. Öğrenme için bir araç olarak teknoloji kullanmada yeteneklerimi geliştirmeye çalışırım.

b. Çoğu arkadaşım ders sırasında teknolojiyi öğrenmek için bir araç olarak kullanmayı öğrenir.

c. Öğrenme için teknoloji kullanma becerilerimi etkili bir şekilde değerlendiririm.

\begin{tabular}{|c|c|c|c|c|}
\hline Nadiren & Ara sira & $\begin{array}{c}\text { Orta } \\
\text { ölçüde }\end{array}$ & $\begin{array}{l}\text { Büyük } \\
\text { ölçüide }\end{array}$ & $\begin{array}{c}\text { Çok } \\
\text { büyük } \\
\text { ölçüde }\end{array}$ \\
\hline $\mathrm{O}$ & $\mathrm{O}$ & $\mathrm{O}$ & $\mathrm{O}$ & $\mathrm{O}$ \\
\hline $\mathrm{O}$ & $\mathrm{O}$ & $\mathrm{O}$ & $\mathrm{O}$ & $\mathrm{O}$ \\
\hline $\mathrm{O}$ & $\mathrm{O}$ & $\mathrm{O}$ & $\mathrm{O}$ & $\mathrm{O}$ \\
\hline $\mathrm{O}$ & $\mathrm{O}$ & $\mathrm{O}$ & $\mathrm{O}$ & $\mathrm{O}$ \\
\hline $\mathrm{O}$ & $\mathrm{O}$ & $\mathrm{O}$ & $\mathrm{O}$ & $\mathrm{O}$ \\
\hline $\mathrm{O}$ & $\mathrm{O}$ & $\mathrm{O}$ & $\mathrm{O}$ & $\mathrm{O}$ \\
\hline $\mathrm{O}$ & $\mathrm{O}$ & $\mathrm{O}$ & $\mathrm{O}$ & $\mathrm{O}$ \\
\hline $\mathrm{O}$ & $\mathrm{O}$ & $\mathrm{O}$ & $\mathrm{O}$ & $\mathrm{O}$ \\
\hline Nadiren & Ara sira & $\begin{array}{c}\text { Orta } \\
\text { ölçüude }\end{array}$ & $\begin{array}{l}\text { Büyük } \\
\text { ölçüde }\end{array}$ & $\begin{array}{c}\text { Çok } \\
\text { büyük } \\
\text { ölçüde }\end{array}$ \\
\hline $\mathrm{O}$ & $\mathrm{O}$ & $\mathrm{O}$ & $\mathrm{O}$ & $\mathrm{O}$ \\
\hline $\mathrm{O}$ & $\mathrm{O}$ & $\mathrm{O}$ & $\mathrm{O}$ & $\mathrm{O}$ \\
\hline $\mathrm{O}$ & $\mathrm{O}$ & $\mathrm{O}$ & $\mathrm{O}$ & $\mathrm{O}$ \\
\hline
\end{tabular}

